\title{
Discrete, Hexagonal Boronate Ester-Linked Macrocycles Related to Two-Dimensional Covalent Organic Frameworks
}

Anton D. Chavez, ${ }^{1}$ Brian J. Smith, ${ }^{1}$ Merry K. Smith, ${ }^{3}$ Peter A. Beaucage, ${ }^{2}$ Brian H. Northrop ${ }^{3}$ and William R. Dichtel ${ }^{1, *}$

${ }^{1}$ Department of Chemistry and Chemical Biology, Cornell University, Baker Laboratory, Ithaca, New York, 14853 USA

${ }^{2}$ Department of Materials Science and Engineering, Cornell University, Ithaca, New York, 14853 USA

${ }^{3}$ Department of Chemistry, Wesleyan University, Middletown, Connecticut 06459 USA

\section{Supporting Information}

\section{Correspondence Address}

\section{Professor William R. Dichtel}

Department of Chemistry and Chemical Biology

Cornell University

Baker Laboratory

Ithaca, NY 14853-1301 (USA)

Tel: (+1)-607-254-2356

Email:wdichtel@cornell.edu

\section{Table of Contents}

I. Materials and Instrumentation

S-2

II. Synthetic Procedures

S-3

III. Additional Characterization

S-11

IV. References

S-28 


\section{Materials and Instrumentation}

Materials. All reagents were purchased from commercial sources and used without further purification. Compounds 2,3-bis(hexyloxy)-6,7,10,11-tetrahydroxytriphenylene (C6THTP), S3, and S5 were synthesized as previously reported. ${ }^{1} \mathrm{MeOH}$ was purchased from a commercial source and purified using a custom-built alumina column-based solvent purification system. Other solvents were purchased from commercial sources and dried over activated $3 \AA \AA$ molecular sieves.

Instrumentation. NMR spectra were recorded on a Varian INOVA $400 \mathrm{MHz}$ spectrometer using a standard ${ }^{1} \mathrm{H}\left\{{ }^{13} \mathrm{C},{ }^{15} \mathrm{~N}\right\}$ Z-PFG probe with a $20 \mathrm{~Hz}$ sample spin rate.

Powder X-ray diffraction (PXRD) patterns were obtained on a Scintag ThetaTheta Powder X-Ray Diffractometer in reflectance Bragg-Brentano geometry employing $\mathrm{Cu}$ Ka line focused radiation at $2200 \mathrm{~W}(40 \mathrm{kV}, 40 \mathrm{~mA})$ power and equipped with a Ge crystal detector fitted with a $0.3 \mathrm{~mm}$ radiation entrance slit. Samples were mounted on zero background sample holders by dropping powders from a spatula and then leveling the sample surface with a glass microscope slide. No sample grinding or sieving was used prior to analysis. Crystallite size was determined by applying the Scherrer equation to the powder patterns using MDI JADE. The Accelrys ${ }^{2}$ Materials Studio (version 5.5) program suite was used to simulate the powder diffraction of the macrocycles. The structures were optimized using the Geometry Optimization routine including energy minimization with cell parameters optimization, using the parameters from the Universal Force Field. ${ }^{3}$ An external pressure of $1 \mathrm{GPa}$ was applied and then released. The PXRD was calculated for the relaxed structures with the Reflex Plus module.

UV/Vis/NIR absorbance and turbidity spectra were recorded on a Cary 5000 UV/Vis/NIR spectrophotometer with a mercury lamp. Cuvette temperature and stirring were regulated with a Quantum Northwest Temperature Controller.

Sonication was performed with a Branson 3510 ultrasonic cleaner with a power output of $100 \mathrm{~W}$ and a frequency of $40 \mathrm{kHz}$.

Scanning electron microscopy was performed on a LEO 1550 FESEM (Keck SEM) operating at $2.00 \mathrm{kV}$ and a working distance of $4-5 \mathrm{~mm}$ with an aperture size of $30 \mu \mathrm{m}$. Samples were prepared by adsorption onto a silicon wafer, which was then 
attached to a flat aluminum platform sample holder. The sample was then placed directly into the instrument. No metal coating was applied.

Wide angle X-ray scattering (WAXS) was performed at the G1 station of the Cornell High Energy Synchrotron Source (CHESS) with a typical beam energy of 10 $\mathrm{keV}$ and sample-to-detector distance of $20 \mathrm{~cm}$. The two- dimensional patterns obtained from a point-collimated beam were azimuthally integrated using the Nika software package $^{4}$ to yield the one-dimensional plot shown in Figure 4. 


\section{Synthetic Procedures}

General procedure for 1 and the homogeneous synthesis of C6THTP macrocycles 2,3-bis(hexyloxy)-6,7,10,11-tetrahydroxytriphenylene (C6THTP) (89 mg, $0.18 \mathrm{mmol}$ ) 1,4-phenylenebis(boronic acid) (PBBA) (30 mg, $0.18 \mathrm{mmol}$ ) and $\mathrm{MeOH}(73 \mu \mathrm{L}, 1.8$ $\mathrm{mmol})$ were dissolved in a dioxane / mesitylene solution $(4: 1 \mathrm{v} / \mathrm{v}, 15 \mathrm{~mL})$ and sonicated for 1 minute. The solution was then filtered $(0.45 \mu \mathrm{m}$ PTFE) to remove residual particulate. In a $20 \mathrm{~mL}$ scintillation vial, the solution was heated to $90{ }^{\circ} \mathrm{C}$ for $12 \mathrm{~h}$ under atmospheric pressure. A precipitate is generally visible within the first few minutes. After cooling to room temperature, the solid was isolated by filtration and briefly rinsed with dioxane/mesitylene solution $(4: 1 \mathrm{v} / \mathrm{v})$. The solid was subsequently dried under vacuum at room temperature, yielding 1 as an off-white powder (63.6 $\mathrm{mg}, 60 \%$ yield by mass). For 3, 2,7-pyrenebis(boronic acid) (PyBBA) was heated in the solvent mixture at $90{ }^{\circ} \mathrm{C}$ until it fully dissolved (5-10 mins) and cooled to rt before adding C6THTP.

\section{General procedure for homogenous synthesis of HxgTHTP macrocycles}

2,3-bis(hexa(ethylene glycol) monomethyl ether)-6,7,10,11-tetrahydroxytriphenylene (HxgTHTP) (106 mg, 0.120 mmol), 1,4-phenylenebis(boronic acid) (PBBA) (20 mg, 0.12 $\mathrm{mmol})$ and $\mathrm{MeOH}(49 \mu \mathrm{L}, 1.2 \mathrm{mmol})$ were dissolved in a dioxane / mesitylene solution $(4: 1 \mathrm{v} / \mathrm{v}, 10 \mathrm{~mL})$ at room temperature and sonicated for $1 \mathrm{~min}$. The solution was then filtered $(0.45 \mu \mathrm{m}$ PTFE) to remove any trace residual particulate. In a $20 \mathrm{~mL}$ scintillation vial, the solution was heated to $90^{\circ} \mathrm{C}$ for $48 \mathrm{~h}$ under atmospheric pressure. The solution was then cooled to rt and added dropwise into hexanes $(100 \mathrm{~mL})$. The solvent was carefully decanted to yield 4 was a brown solid ( $87 \mathrm{mg}, 75 \%$ yield). 


\section{Macrocycle Swelling.}

$20 \mathrm{mg}$ of 1 was suspended in $8 \mathrm{~mL}$ dioxane / mesitylene solution $(4: 1 \mathrm{v} / \mathrm{v})$. The suspension was sonicated for 30 seconds and then centrifuged. The supernatant was removed and PXRD pattern of the resulting paste was obtained by spreading it on the sample holder. The sample was then collected and dried overnight under vacuum and its PXRD pattern was obtained again. This procedure was repeated at least two more times for the same sample.

\section{Water Digestion Experiments ${ }^{5}$}

Suspensions of either 1 or COF-5 (both $0.5 \mathrm{mg} / \mathrm{mL}$ ) were prepared in $1.5 \mathrm{~mL}$ dioxane/mesitylene $(4: 1 \mathrm{v} / \mathrm{v})$ in a septum-sealed, screw-capped cuvette. The solution was rapidly and constantly stirred throughout the measurement to prevent precipitate settling and maintain uniform distribution. $\mathrm{H}_{2} \mathrm{O}\left(40 \mu \mathrm{L}, 1.5 \mathrm{M}\right.$ final $\left.\left[\mathrm{H}_{2} \mathrm{O}\right]\right)$ was introduced via syringe, and the absorbance was monitored at $1310 \mathrm{~nm}(1 \mathrm{~cm}$ path length).

\section{GPC Kinetics Experiments.}

Samples were prepared as described above for the synthesis of HxgTHTP macrocycles, except the samples contained $0.0,0.1$, or 1.0 equiv of 4 -tert-butylcatechol (TCAT). The samples were heated to $90^{\circ} \mathrm{C}$ for 10 days, after which a $100 \mu \mathrm{L}$ aliquot was taken from each sample and diluted with $1 \mathrm{~mL}$ of THF. The samples were then analyzed by gel permeation chromatography and the refractive indices were normalized to the eluted dioxane peak. 
Scheme S1. Synthesis of S1.

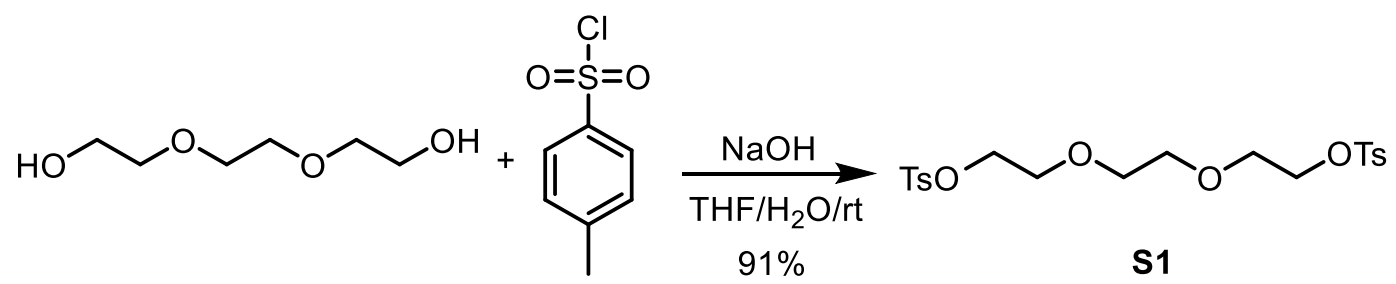

Synthesis of $\mathrm{S1}: \mathrm{NaOH}(18.4 \mathrm{~g}, 459 \mathrm{mmol})$ was dissolved in $25 \mathrm{~mL}$ of water in a 500 $\mathrm{mL}$ round bottom flask equipped with a magnetic stirrer. Triethyleneglycol (30.0 g, 200 $\mathrm{mmol}$ ) and THF (125 mL) were added and stirred at $\mathrm{rt}$ for $1 \mathrm{~h}$ before being cooled to 0 ㄷ. 4-toluenesulfonyl chloride $(76.0 \mathrm{~g}, 400 \mathrm{mmol}$ ) was slowly added (over the course of $30 \mathrm{~min}$ ) to the cold basic solution while stirring. The mixture was warmed to room temperature and stirred for $12 \mathrm{~h}$, after which it was diluted with water $(100 \mathrm{~mL})$ and aqueous $\mathrm{HCl}(6 \mathrm{M}, 50 \mathrm{~mL})$. The acidified mixture was extracted with $\mathrm{CH}_{2} \mathrm{Cl}_{2}(3 \times 100$ $\mathrm{mL})$. The combined organic extracts were rinsed with water $(2 \times 100 \mathrm{~mL})$, dried over anhydrous $\mathrm{MgSO}_{4}$, and concentrated in a rotary evaporator yielding $\mathbf{S} 1$ (82.9 g, 91\% yield) as an off white solid. ${ }^{1} \mathrm{H} \mathrm{NMR}\left(400 \mathrm{MHz}, \mathrm{CDCl}_{3}\right) \delta 7.79(\mathrm{~d}, \mathrm{~J}=8.3 \mathrm{~Hz}, 4 \mathrm{H}), 7.34$ (d, J = 8.3 Hz, 4H), 4.14 (t, J = 4.6 Hz, 4H), 3.65 (t, J = 4.7 Hz, 4H), 3.52 (s, 4H), 2.44 (s, 6H). ${ }^{13} \mathrm{C}$ NMR $\left(100 \mathrm{MHz}, \mathrm{CDCl}_{3}\right) \delta 144.97,133.00,129.95,128.02,70.74,70.54$, 69.31, 68.81, 21.73. DART HRMS $\mathrm{m} / \mathrm{z}$ calcd. for $\mathrm{C}_{20} \mathrm{H}_{27} \mathrm{O}_{8} \mathrm{~S}_{2}\left([\mathrm{M}+\mathrm{H}]^{+}\right)$459.11419, found 459.11324 . These analyses are consistent with a previous report. ${ }^{6}$ 
Scheme S2. Synthesis of S2.

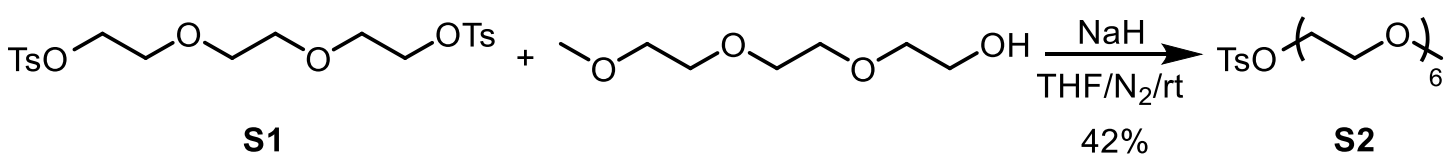

Synthesis of S2. S1 ( $40.0 \mathrm{~g}, 87.2 \mathrm{mmol})$ was dissolved in anhydrous THF (250 mL) in a flame dried $1000 \mathrm{~mL}$ flask equipped with a magnetic stir bar. Sodium hydride $(1.125 \mathrm{~g}$, $46.89 \mathrm{mmol}$ ) was loaded in a flame-dried $500 \mathrm{~mL}$ flask equipped with a magnetic stir bar. The flask was evacuated and backfilled with $\mathrm{N}_{2}$ three times. Anhydrous THF (250 $\mathrm{mL}$ ) was added via cannula. Triethyleneglycol monomethyl ether $(7.00 \mathrm{~g}, 42.6 \mathrm{mmol})$ was added dropwise to the sodium hydride solution at $r$, and the mixture was stirred for $2 \mathrm{~h}$ after $\mathrm{H}_{2}$ bubbling ceased. The triethyleneglycol/hydride/THF solution was then transferred drop-wise (30 min) into a vigorously stirred S2/THF solution via a cannula and the mixture was stirred at room temperature for $24 \mathrm{~h}$ under $\mathrm{N}_{2}$. The solution was then acidified with aqueous $\mathrm{HCl}(2 \mathrm{M}, 100 \mathrm{~mL})$. The majority of the THF was removed by rotary evaporation and the resulting solution was extracted with $\mathrm{CH}_{2} \mathrm{Cl}_{2}(3 \times 150 \mathrm{~mL})$. The combined organic extractions were dried over anhydrous $\mathrm{MgSO}_{4}$ and concentrated under vacuum using a rotary evaporator. The resulting residue was purified by column chromatography $\left(\mathrm{SiO}_{2}, 30 \% \mathrm{v} / v\right.$ acetone $\left./ \mathrm{CH}_{2} \mathrm{Cl}_{2}\right)$ to provide $\mathbf{S} 2(8.2 \mathrm{~g}, 42 \%$ yield) as a light yellow oil. ${ }^{1} \mathrm{H}$ NMR $\left(400 \mathrm{MHz}, \mathrm{CDCl}_{3}\right) \delta 7.77(\mathrm{~d}, \mathrm{~J}=8.3 \mathrm{~Hz}, 2 \mathrm{H}), 7.33(\mathrm{~d}, \mathrm{~J}=8.3$ $\mathrm{Hz}, 2 \mathrm{H}), 4.13(\mathrm{t}, \mathrm{J}=4.7,2 \mathrm{H}), 3.67-3.51(\mathrm{~m}, \mathrm{br}, 22 \mathrm{H}), 3.35(\mathrm{~s}, 3 \mathrm{H}), 2.43(\mathrm{~s}, 3 \mathrm{H}) .{ }^{13} \mathrm{C} \mathrm{NMR}$ $\left(100 \mathrm{MHz}, \mathrm{CDCl}_{3}\right) \delta 144.59,133.76,129.64,127.71,71.68,70.45,70.34,70.30$ (br), 70.26, 69.12, 68.40, 58.75, 21.40 DART HRMS $\mathrm{m} / \mathrm{z}$ calcd. for $\mathrm{C}_{20} \mathrm{H}_{35} \mathrm{O}_{9} \mathrm{~S}\left([\mathrm{M}+\mathrm{H}]^{+}\right)$ 451.19963 , found 459.19864 . These analyses are consistent with a previous report. ${ }^{7}$ 
Scheme S3. Synthesis of compound S4

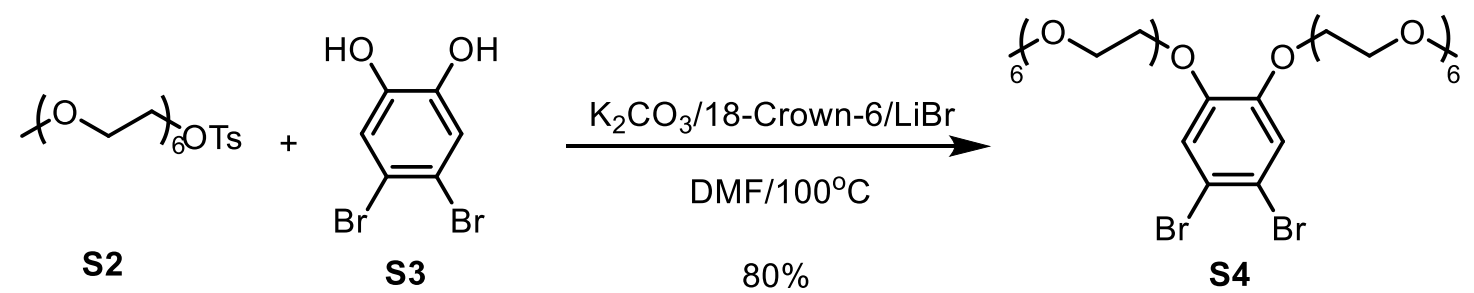

Synthesis of S4. S3 (1.20 g, $4.48 \mathrm{mmol})$ and S2 $(5.05 \mathrm{~g}, 11.2 \mathrm{mmol})$ were dissolved in DMF (45 mL) followed by the addition of $\mathrm{K}_{2} \mathrm{CO}_{3}(2.48 \mathrm{~g}, 17.9 \mathrm{mmol}), \mathrm{LiBr}(39 \mathrm{mg}, 0.45$ $\mathrm{mmol}$ ), and 18-crown-6 (120 mg, $0.45 \mathrm{mmol})$. The solution was sparged with $\mathrm{N}_{2}$ for 15 min before heating to $100{ }^{\circ} \mathrm{C}$ for $14 \mathrm{~h}$. The solution was then cooled to $\mathrm{rt}$ and poured into $\mathrm{H}_{2} \mathrm{O}(250 \mathrm{~mL})$ and extracted with $\mathrm{CHCl}_{3}(3 \times 100 \mathrm{~mL})$. The solvent was evaporated by rotary evaporation to provide the crude mixture, which was purified by chromatography $\left(\mathrm{SiO}_{2}, 50 \% \mathrm{v} / \mathrm{v}\right.$ acetone: $\left.\mathrm{CH}_{2} \mathrm{Cl}_{2}\right)$, to provide $\mathbf{S} 3(2.93 \mathrm{~g}, 80 \%$ yield) as a light yellow, viscous oil. ${ }^{1} \mathrm{H} \mathrm{NMR}\left(400 \mathrm{MHz}, \mathrm{CDCl}_{3}\right) \delta 7.15(\mathrm{~s}, 2 \mathrm{H}), 4.13(\mathrm{t}, \mathrm{J}=4.9 \mathrm{~Hz}$, $4 \mathrm{H}), 3.84(\mathrm{t},=4.9 \mathrm{~Hz}, 4 \mathrm{H}), 3.71(\mathrm{~m}, 4 \mathrm{H}), 3.65(\mathrm{~m}, 32 \mathrm{H}), 3.54(\mathrm{~m}, 4 \mathrm{H}), 3.38(\mathrm{~s}, 6 \mathrm{H}) .{ }^{13} \mathrm{C}$ NMR $\left(100 \mathrm{MHz}, \mathrm{CDCl}_{3}\right) \delta 148.89,119.14,115.31,71.94,70.89,70.67,70.64,70.61$ (br), 70.58, 70.53, 69.59, 69.32, 59.05. DART HRMS $m / z$ calcd. for $\mathrm{C}_{32} \mathrm{H}_{57} \mathrm{O}_{14} \mathrm{Br}_{2}([\mathrm{M}+$ $\mathrm{H}]^{+}$) 823.21151, found 823.21549. 
Scheme S4. Synthesis of compound S6<smiles>COCCOc1cc(Br)c(Br)cc1OCCOC</smiles>

S4

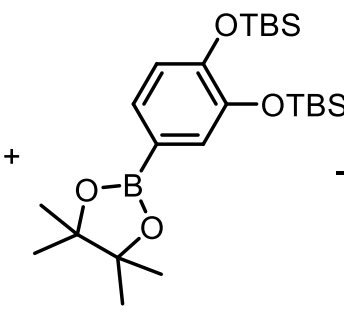

S5

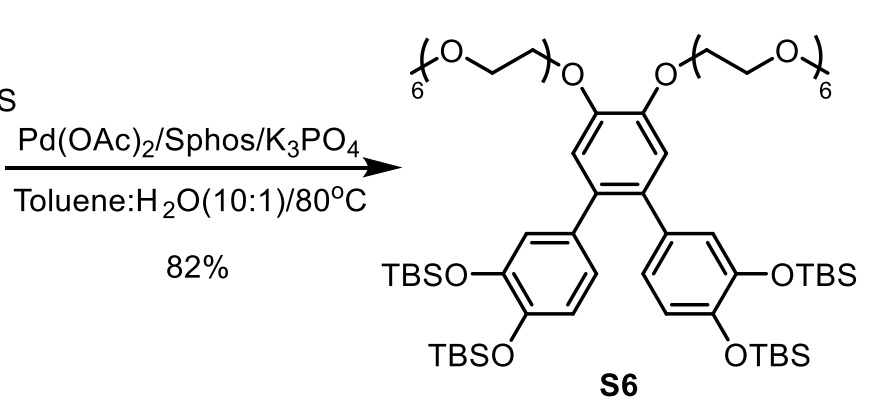

S6

Synthesis of S6. S4 (2.93 g, $3.55 \mathrm{mmol})$, S5 (4.13 g, $8.88 \mathrm{mmol}), \mathrm{K}_{3} \mathrm{PO}_{4}(3.02 \mathrm{~g}, 14.2$ $\mathrm{mmol}$ ) and Sphos (117 $\mathrm{mg}, 0.284 \mathrm{mmol}$ ) were dissolved in a toluene/water mixture $(10: 1 \mathrm{v} / \mathrm{v}, 50 \mathrm{~mL})$. The mixture was then sparged with $\mathrm{N}_{2}$ for 20 minutes after which $\mathrm{Pd}(\mathrm{OAc})_{2}$ (32 $\mathrm{mg}, 0.14 \mathrm{mmol}$ ) is quickly added. The solution was sparged again with $\mathrm{N}_{2}$ for 20 minutes before being heated to $80^{\circ} \mathrm{C}$ for 6 hours. The solution was then cooled to rt, diluted with $\mathrm{CH}_{2} \mathrm{Cl}_{2}(100 \mathrm{~mL})$ and filtered through a plug of celite. The solvent was evaporated by rotary evaporation and purified by chromatography $\left(\mathrm{SiO}_{2}, 33 \% \mathrm{v} / \mathrm{v}\right.$ Acetone: $\left.\mathrm{CH}_{2} \mathrm{Cl}_{2}\right)$, to provide $\mathbf{S 6}\left(3.91 \mathrm{~g}, 82 \%\right.$ yield) as a yellow, viscous oil. ${ }^{1} \mathrm{H}$ NMR $(400 \mathrm{MHz}, \mathrm{CDCl} 3) \delta 6.88 \mathrm{z}(\mathrm{s}, 2 \mathrm{H}), 6.65(\mathrm{~d}, \mathrm{~J}=8.2 \mathrm{~Hz}, 2 \mathrm{H}), 6.61(\mathrm{~d}, \mathrm{~J}=2.1,2 \mathrm{H}), 6.56$ $(\mathrm{dd}, \mathrm{J}=8.2,2.1,2 \mathrm{H}), 4.22(\mathrm{t}, \mathrm{J}=4.9 \mathrm{~Hz}, 4 \mathrm{H}), 3.88(\mathrm{t}, \mathrm{J}=4.0 \mathrm{~Hz}, 4 \mathrm{H}), 3.75(\mathrm{~m}, 4 \mathrm{H})$, 3.66(m, 32H), 3.54(m, 4H), 3.37(s, 6H), $0.98(\mathrm{~s}, 18 \mathrm{H}), 0.93(\mathrm{~s}, 18 \mathrm{H}), 0.19(\mathrm{~s}, 12 \mathrm{H}), 0.07$ (s, $12 \mathrm{H}) .{ }^{13} \mathrm{C}-\mathrm{NMR}\left(100 \mathrm{MHz}, \mathrm{CDCl}_{3}\right) \delta$ 146.60, 146.10, 145.41, 134.80, 133.40, 122.70, 122.47, 120.29, 117.01, 71.91, 70.81, 70.65, 70.58, 70.54 (br), 70.48, 69.77, 69.02, $59.00,25.95,25.91,18.41,18.32,-4.04,-4.17$. DART HRMS $\mathrm{m} / \mathrm{z}$ calcd. for $\mathrm{C}_{68} \mathrm{H}_{123} \mathrm{O}_{18} \mathrm{Si}_{4}\left([\mathrm{M}+\mathrm{H}]^{+}\right) 1339.77810$, found 1339.78089 . 
Scheme S5. Synthesis of HxgTHTP

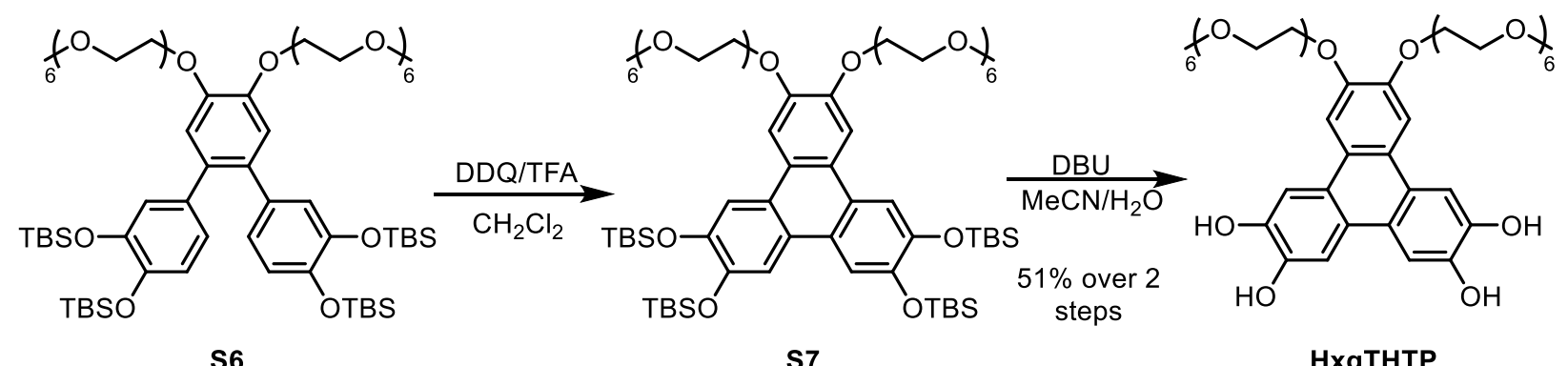

Synthesis of HxgTHTP. S6 (1.30 g, $0.970 \mathrm{mmol})$ was dissolved in dry $\mathrm{CH}_{2} \mathrm{Cl}_{2}(100$ $\mathrm{mL})$. Trifluoroacetic acid $(8 \mathrm{~mL})$ was added and the solution was stirred at $\mathrm{rt}$ for 30 minutes. The solution was then cooled to $0{ }^{\circ} \mathrm{C}$, and DDQ (242 $\mathrm{mg}, 1.07 \mathrm{mmol}$ ) was slowly added with a corresponding color change from light yellow to emerald green. The solution was allowed to warm to rt over the course of $3 \mathrm{~h}$, after which the solution was poured into $\mathrm{H}_{2} \mathrm{O}(200 \mathrm{~mL})$. The mixture was extracted with $\mathrm{CH}_{2} \mathrm{Cl}_{2}(3 \times 75 \mathrm{~mL})$. The combined organic extractions were washed with saturated $\mathrm{NaHCO}_{3}(3 \times 150 \mathrm{~mL})$. The solvent was evaporated by rotary evaporation, yielding crude $\mathbf{S 7}$ as a dark purple oil. The material was used without further purification. Crude $\mathbf{S 7}$ was dissolved in MeCN:H2O (95:5, $8 \mathrm{~mL}$ ), followed by the addition of 1,8-diazabicyclo[5.4.0]undec-7-ene (DBU, $0.49 \mathrm{~mL}, 3.29 \mathrm{mmol}$ ). The solution was stirred at rt for $45 \mathrm{~min}$, after which it was poured into a saturated aqueous $\mathrm{NH}_{4} \mathrm{Cl}$ solution $(50 \mathrm{~mL})$. The product was extracted with $\mathrm{CHCl}_{3}(3 \times 25 \mathrm{~mL})$. The organic layer was then washed with dilute $\mathrm{HCl}(10 \mathrm{mM}, 3 \times$ $50 \mathrm{~mL}$ ). The solvent was evaporated by rotary evaporation to yield crude HxgTHTP, which was purified by rinsing with $\mathrm{Et}_{2} \mathrm{O}$, yielding ( $440 \mathrm{mg}, 51 \%$ over two steps) of a dark red, viscous oil. ${ }^{1} \mathrm{H}$ NMR (400 MHz, acetone-d6) $\delta 8.33$ (s, 2H), 8.17 (s, 2H), 7.97 (s, 2H), $7.95(\mathrm{~s}, 2 \mathrm{H}), 7.84(\mathrm{~s}, 2 \mathrm{H}), 4.41(\mathrm{t}, \mathrm{J}=4.9 \mathrm{~Hz}, 4 \mathrm{H}), 3.94(\mathrm{t}, \mathrm{J}=4.9 \mathrm{~Hz}, 4 \mathrm{H}), 3.75(\mathrm{~m}$, 4H), $3.65(\mathrm{~m}, 4 \mathrm{H}), 3.62-3.52(\mathrm{~m}, 28 \mathrm{H}) 3.44(\mathrm{~m}, 4 \mathrm{H}), 3.26(\mathrm{~s}, 6 \mathrm{H}) .{ }^{13} \mathrm{C}-\mathrm{NMR}(75 \mathrm{MHz}$, acetone-d6) $\delta 149.25,146.16,146.01,124.38,124.12,123.69,109.11,108.66,108.24$, 72.55z, 71.40, 71.26, 70.12 (br), 70.94, 70.50, 69.71, 58.75. DART HRMS m/z calcd. for $\mathrm{C}_{44} \mathrm{H}_{63} \mathrm{O}_{18}\left([\mathrm{M}-\mathrm{H}]^{-}\right) 879.40144$, found 879.40125 . 


\section{Additional Characterization}

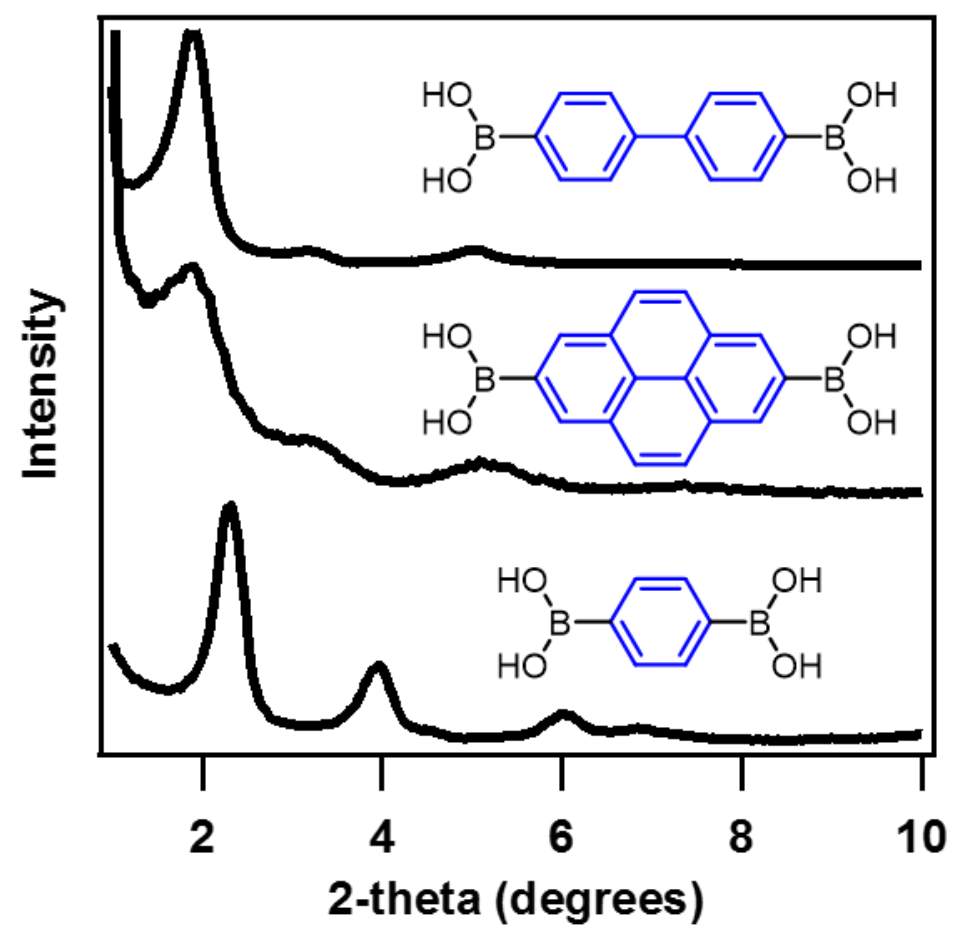

Figure S1. Powder X-ray patterns of C6THTP macrocycles with different linkers, BPBBA (unit cell length = $53 \AA$ ), PyBBA (unit cell length $=53 \AA$ ), and PBBA (unit cell length $=45 \AA$ ) respectively. 


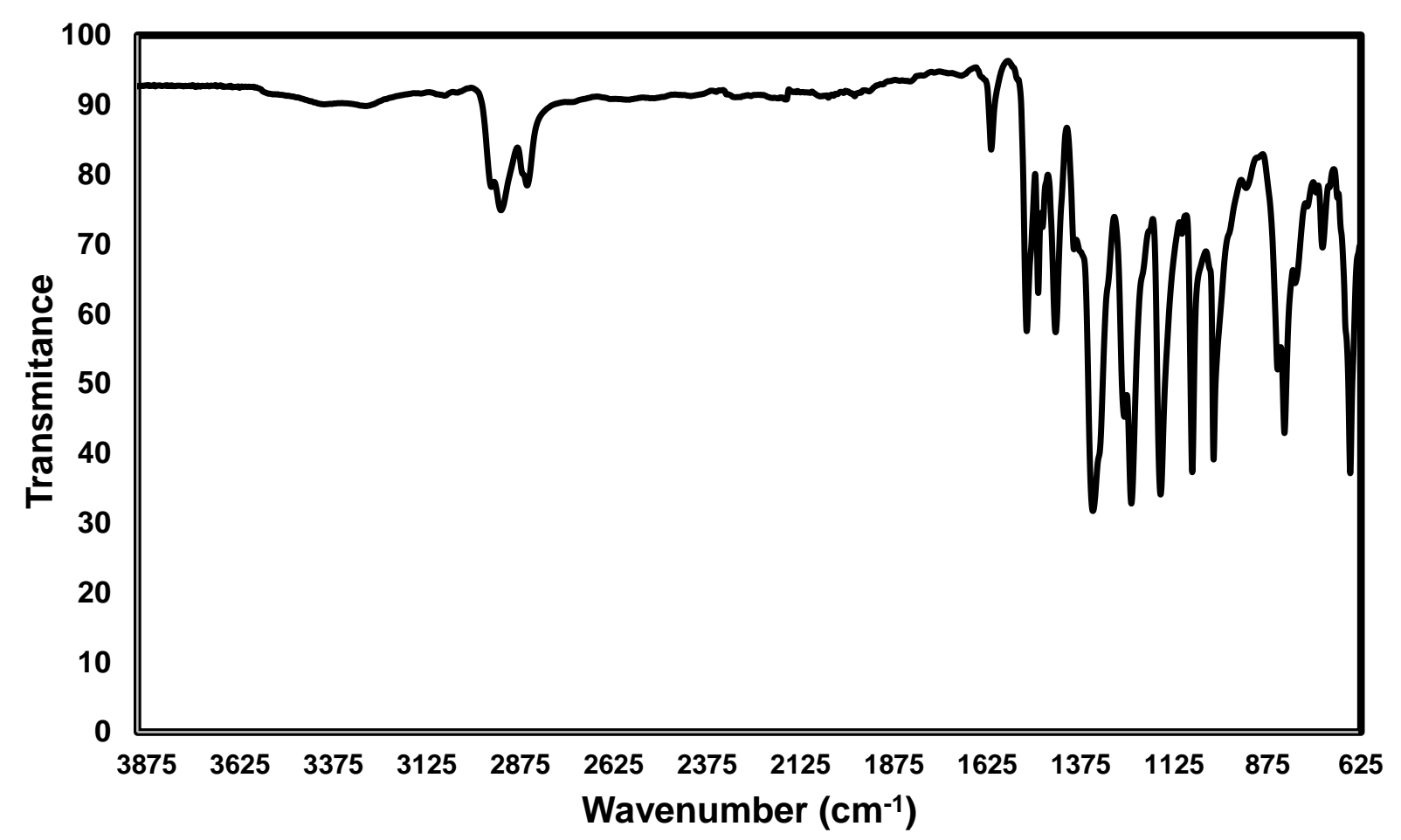

Figure S2. FT-IR spectrum of macrocycle 1 

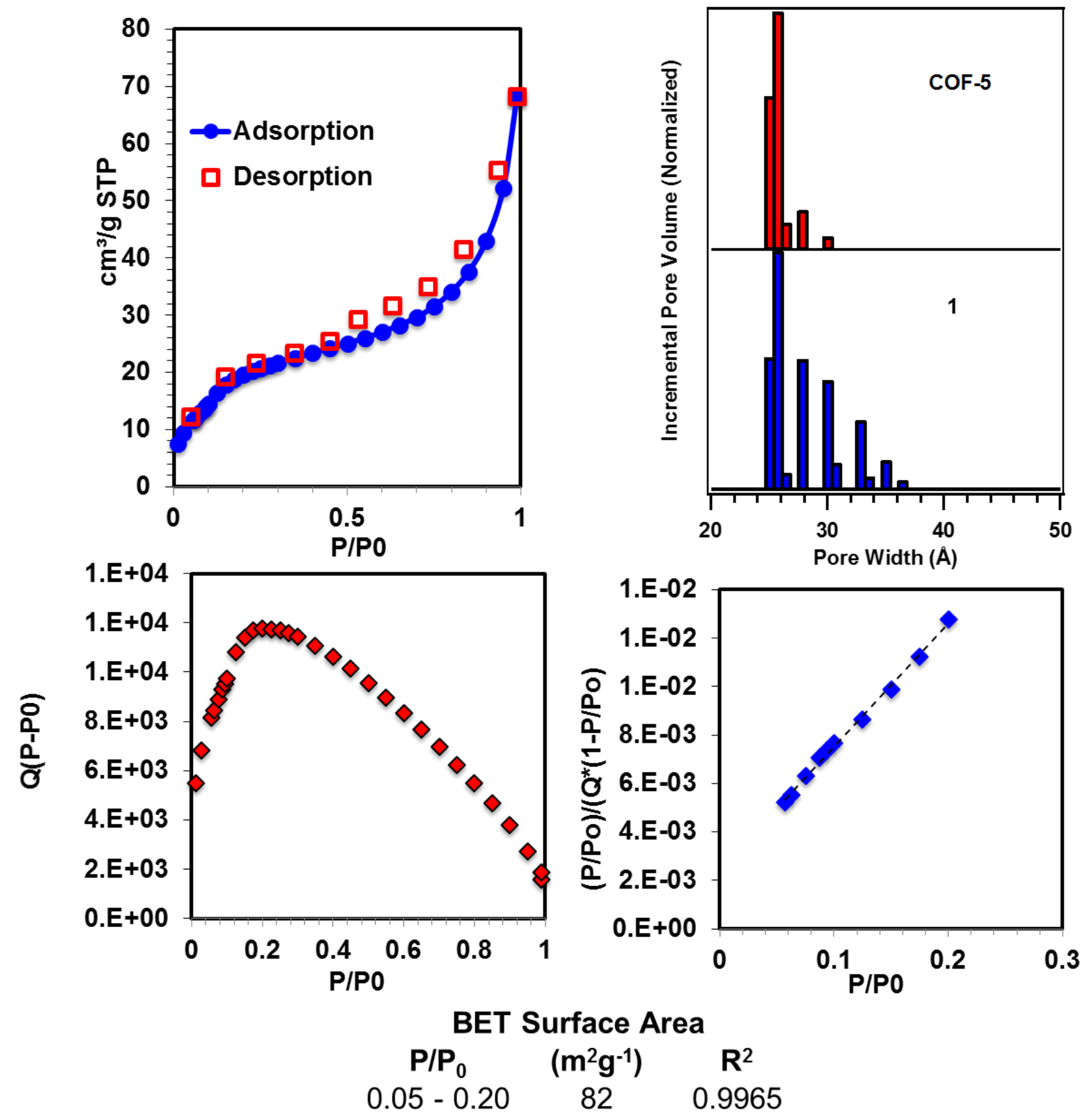

Figure S3. $\mathrm{N}_{2}$ adsorption isotherm $(77 \mathrm{~K})$ and surface area data analysis for 1 . Although most samples of 1 did not appear mesoporous by $\mathrm{N}_{2}$ adsorption, one sample provided a Brunauer-Emmett-Teller surface area $\left(S_{B E T}\right)$ of ca. $82 \mathrm{~m}^{2} \mathrm{~g}^{-1}$ compared to a Connolly surface area of $440 \mathrm{~m}^{2} \mathrm{~g}^{-1}$. 


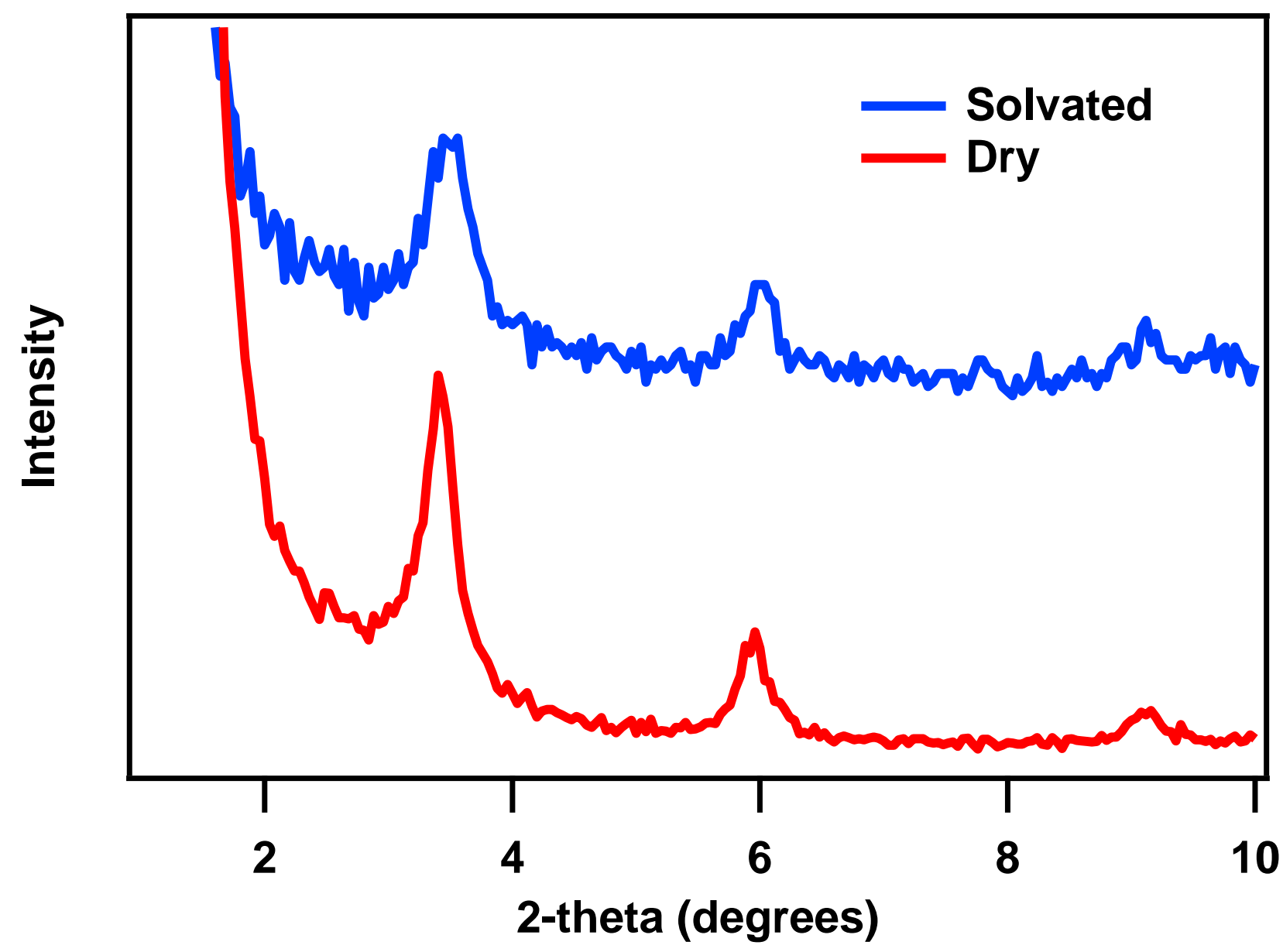

Figure S4. Powder X-ray diffraction of COF-5 either dry (red) or soaked in 4:1 dioxane:mesitylene $(v / v)$ (blue). 


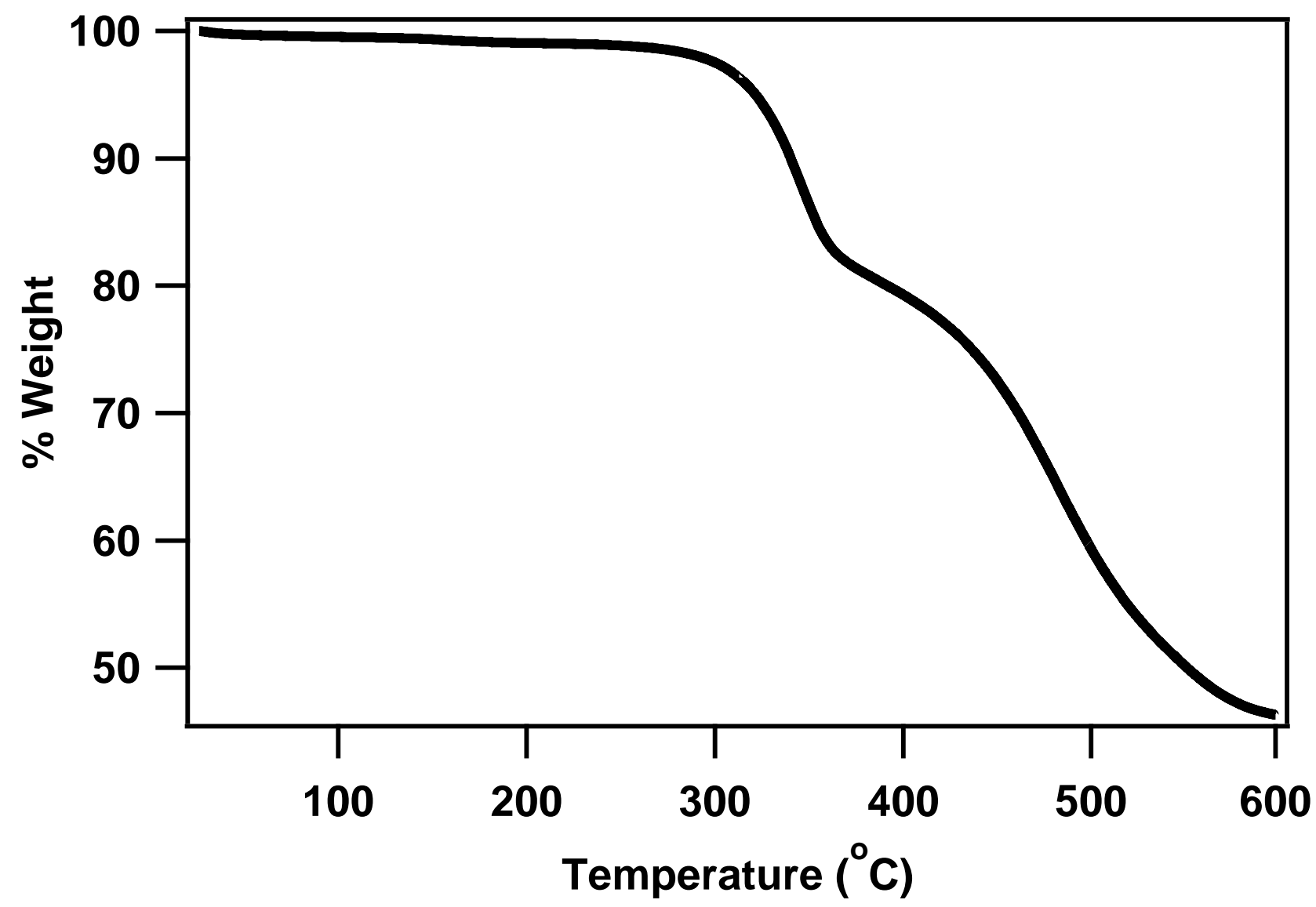

Figure S5. Thermogravimetric analysis of 1. 


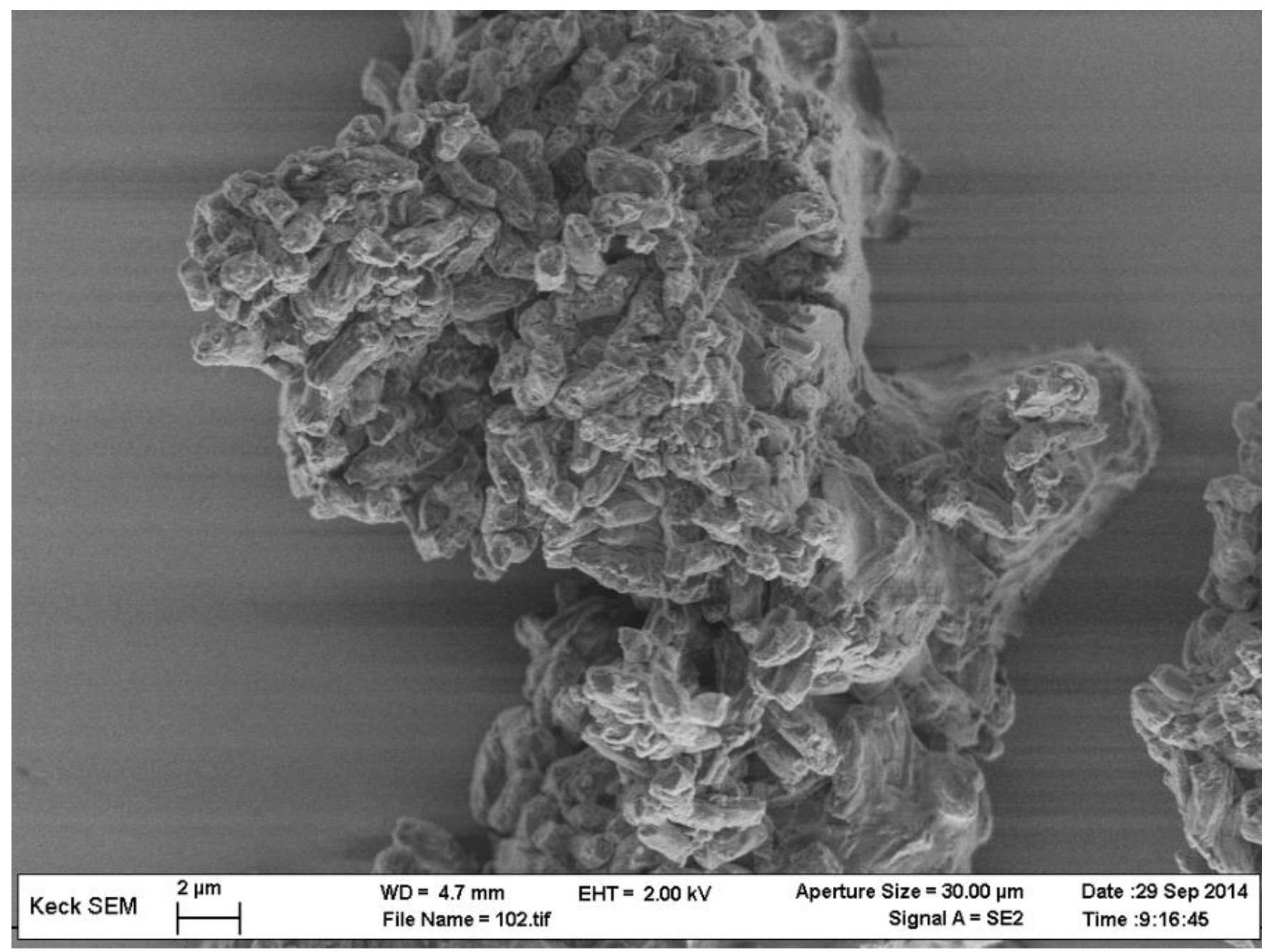

Figure S6. Representative SEM image of 1 isolated as a powder. 


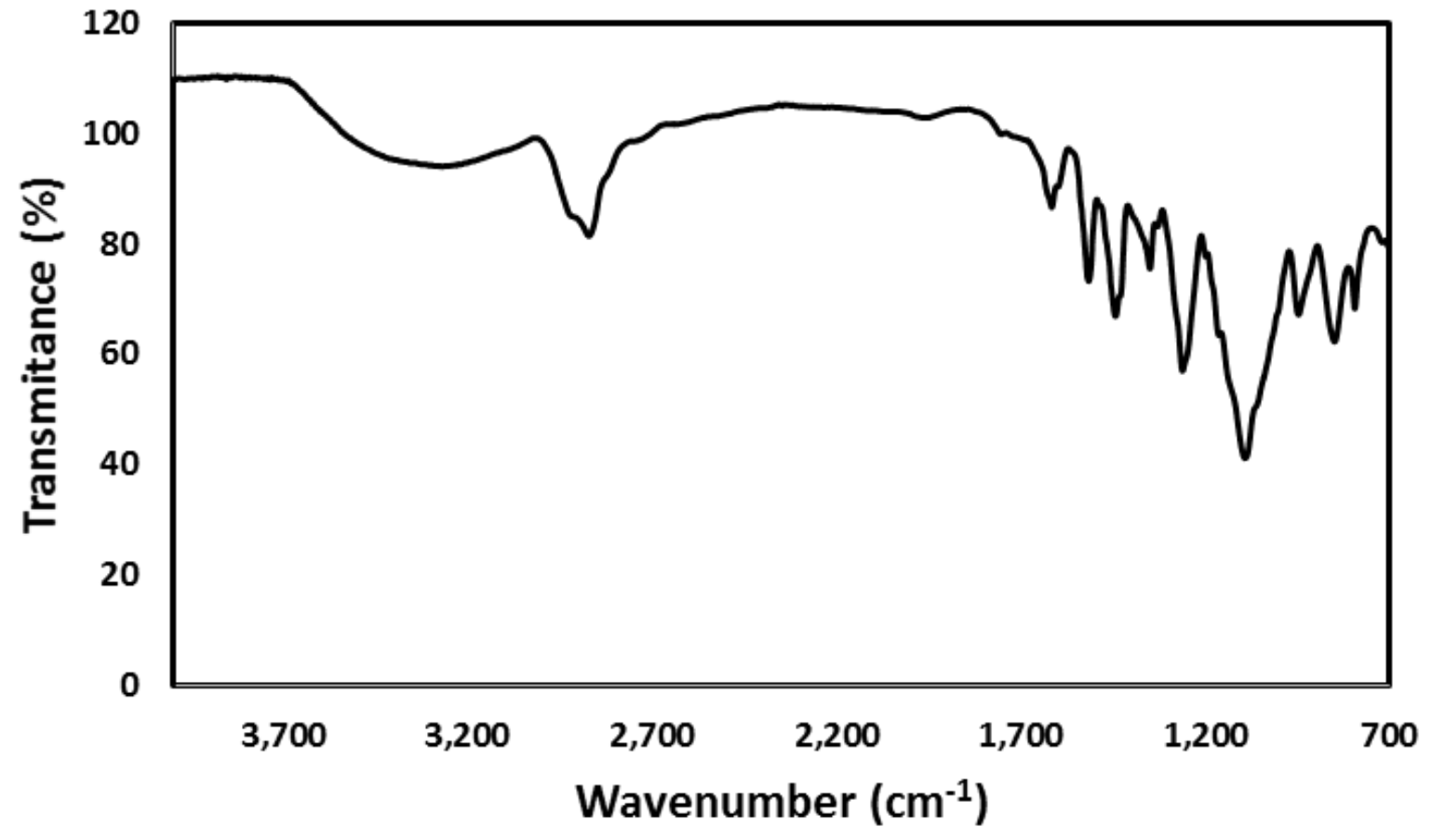

Figure S7. FT-IR spectrum of HxgTHTP.

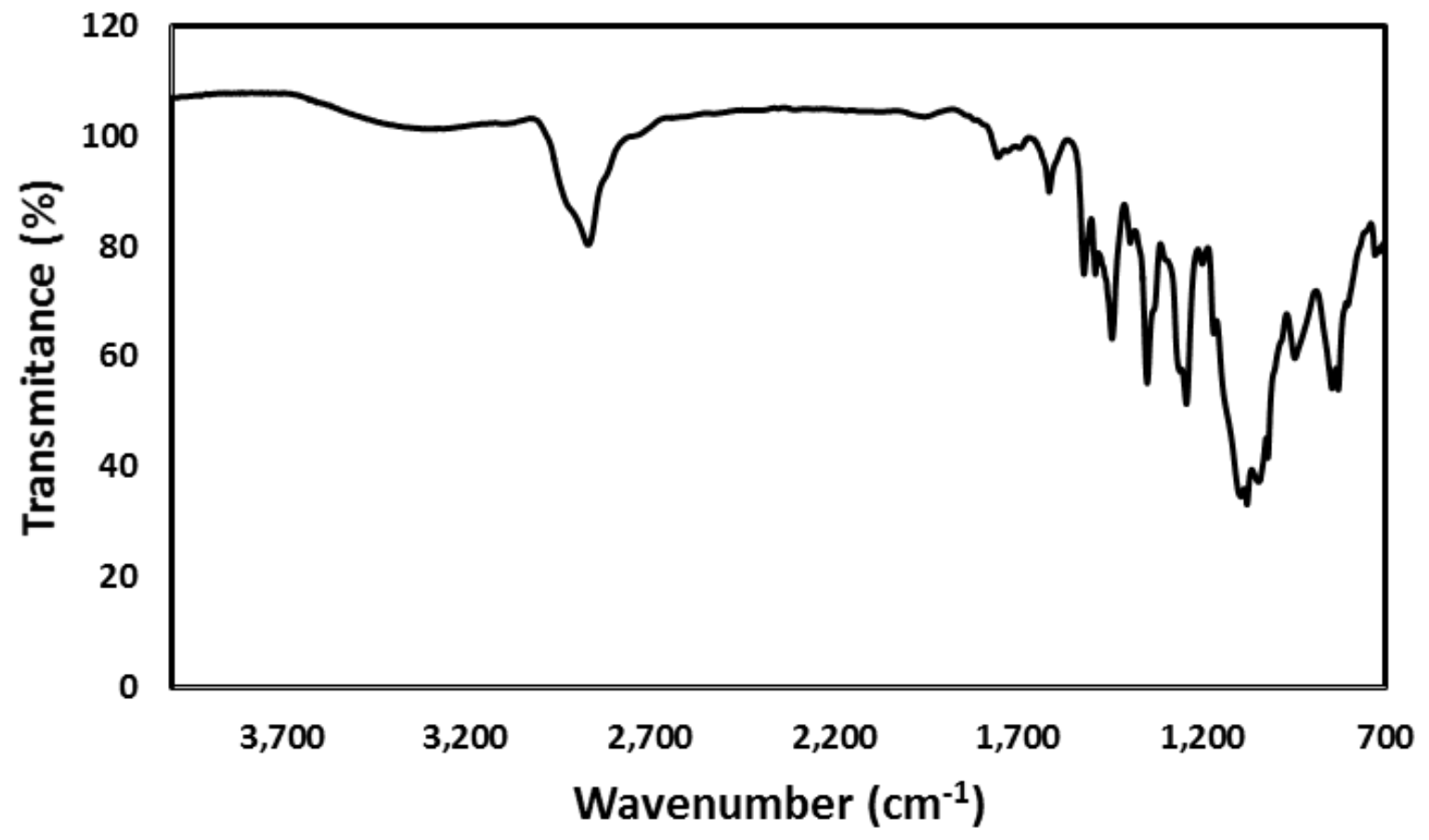

Figure S8. FT-IR spectrum of macrocycle 4. 
<smiles>OCCOCCOCCOCCOc1cc2c3cc(O)c(O)cc3c3cc(O)c(O)cc3c2cc1O</smiles><smiles>OPO</smiles>

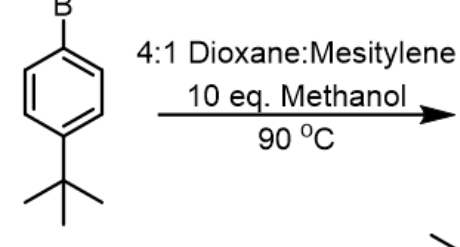<smiles>C/C=C(/C)B1Oc2cc3c4cc(OCCO)c(OCCO)cc4c4cc5c(cc4c3cc2O1)OB(c1ccc(C(C)(C)C)cc1)O5</smiles>

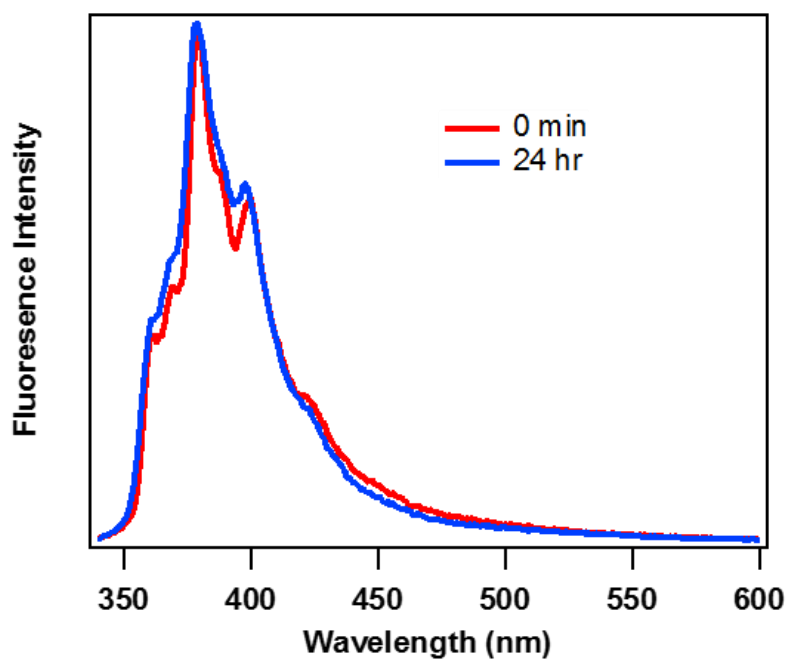

Figure S9. Fluorescence spectra $\left(60 \mu \mathrm{M}, \lambda_{\mathrm{ex}}=325 \mathrm{~nm}\right)$ for the model reaction between HxgTHTP and 4-tert-butylphenylboronic acid under identical conditions for the formation of 4 . 


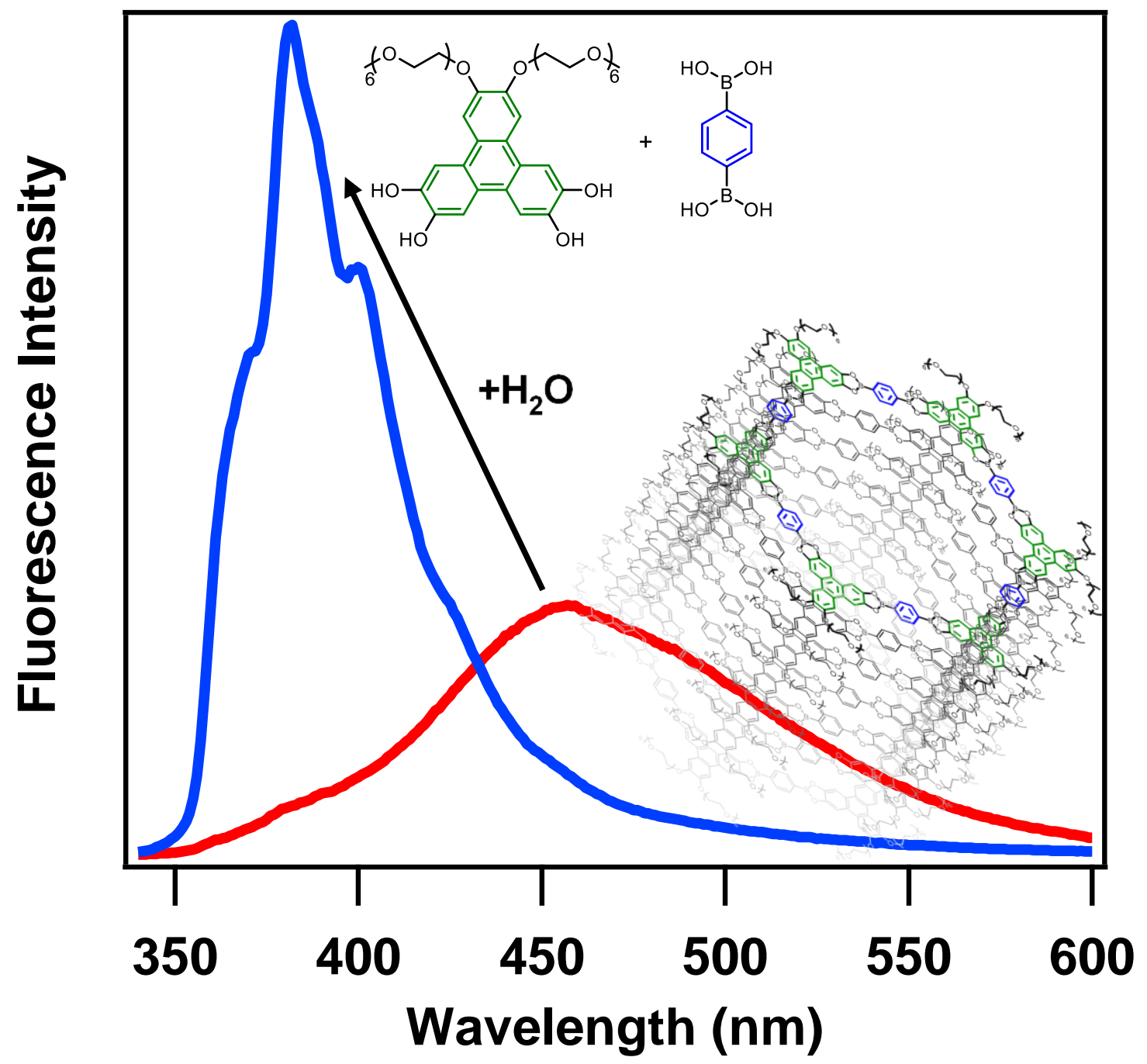

Figure S10. Emission spectra $\left(\lambda_{\mathrm{ex}}=325 \mathrm{~nm}\right)$ for 4 in acetone before and after the addition of water. 


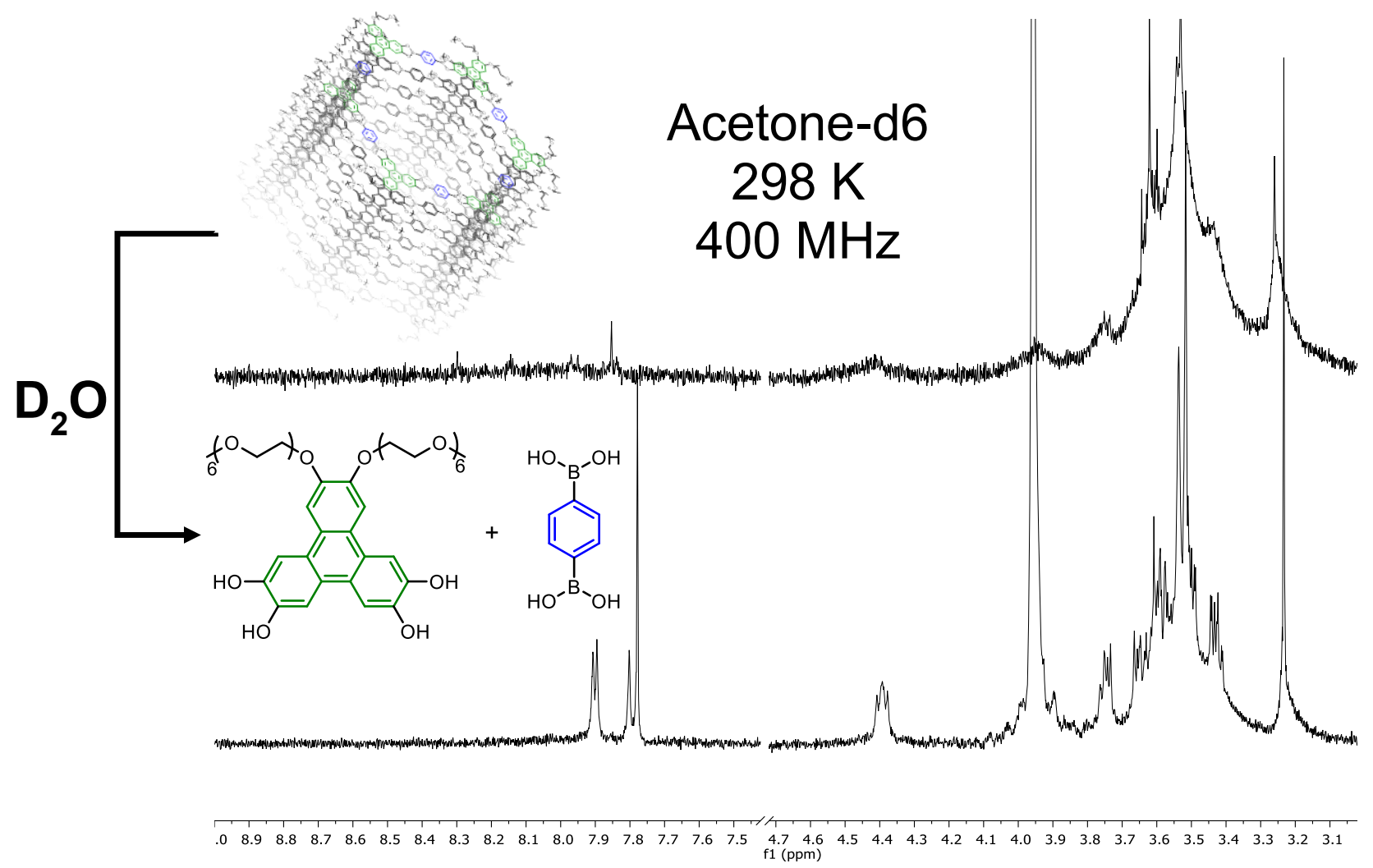

Figure S11. NMR spectra of 4 dissolved in acetone-d6, before and after the addition of $\mathrm{D}_{2} \mathrm{O}$. 


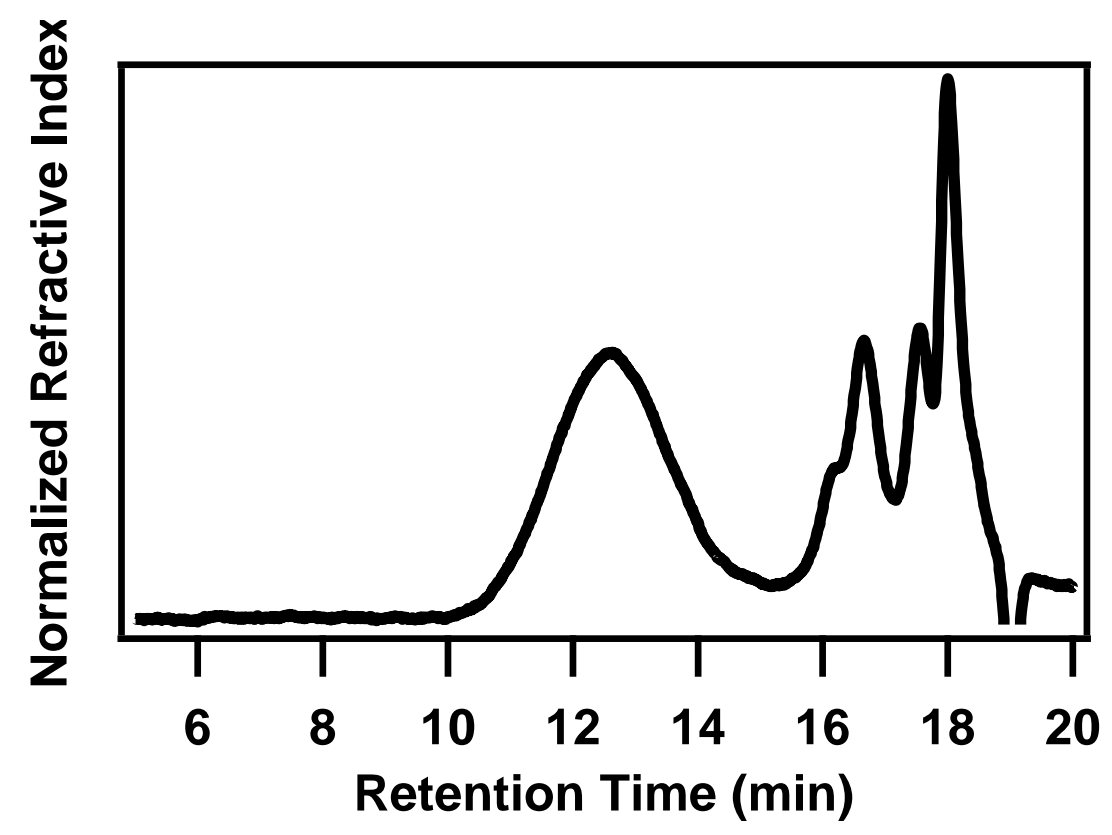

Figure S12. GPC trace of 4 in THF.

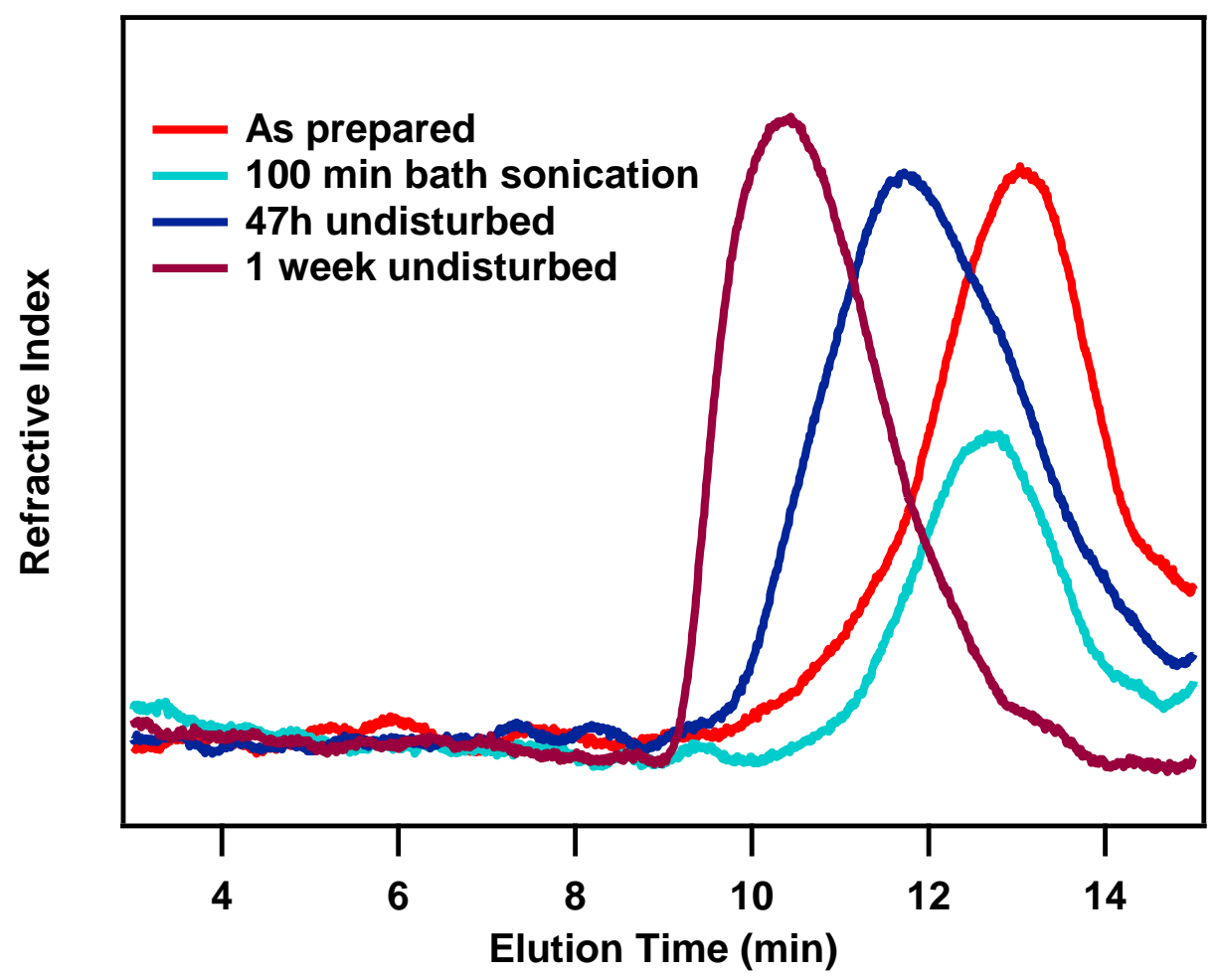

Figure S13. GPC traces of 4 after being sonicated and left undisturbed up to 1 week. 


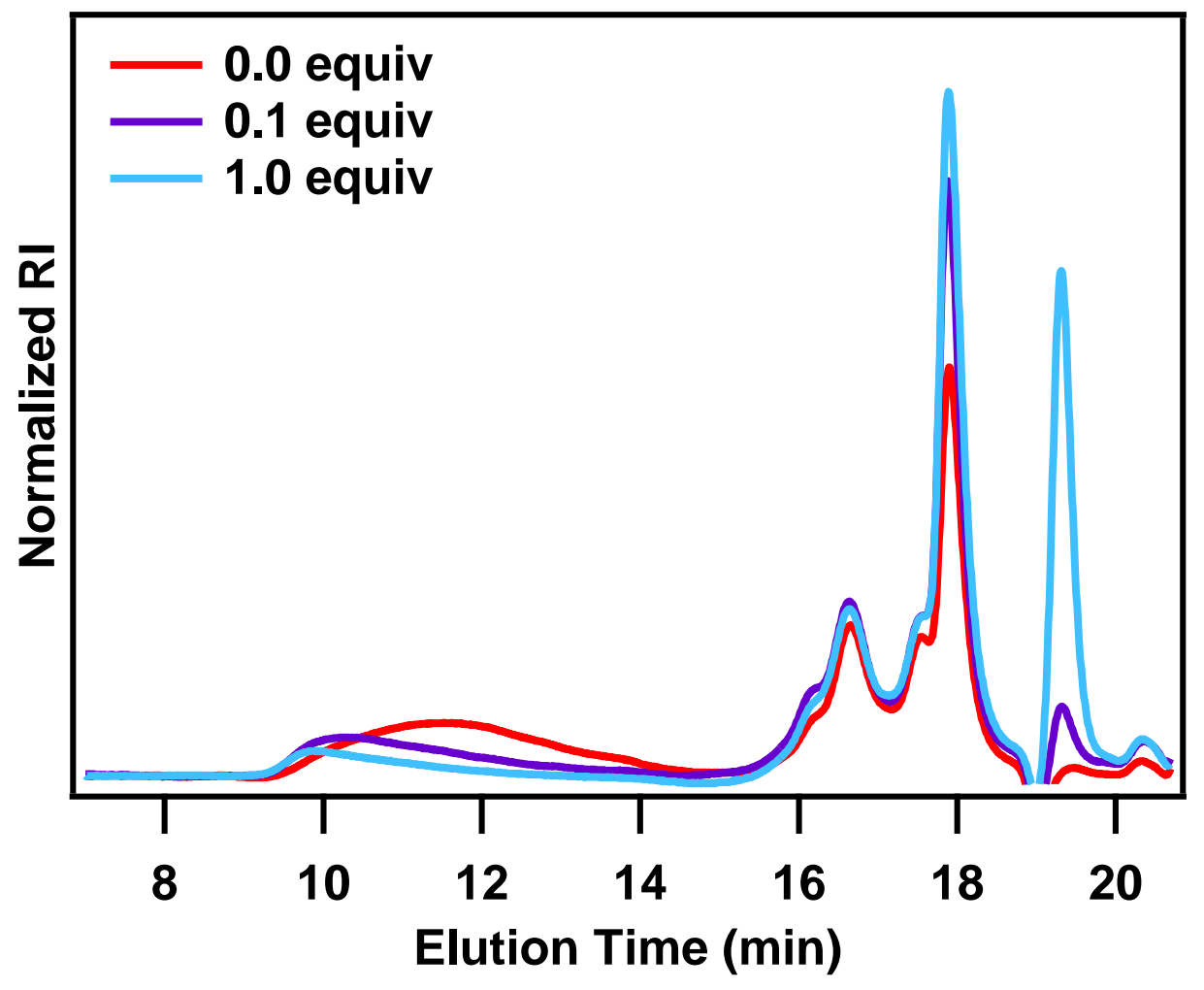

Figure S14. Expanded GPC traces of an aliquot of the reaction between HxgTHTP and PBBA with various equiv. of TCAT heated at $90^{\circ} \mathrm{C}$ for 10 days 
NMR Spectra

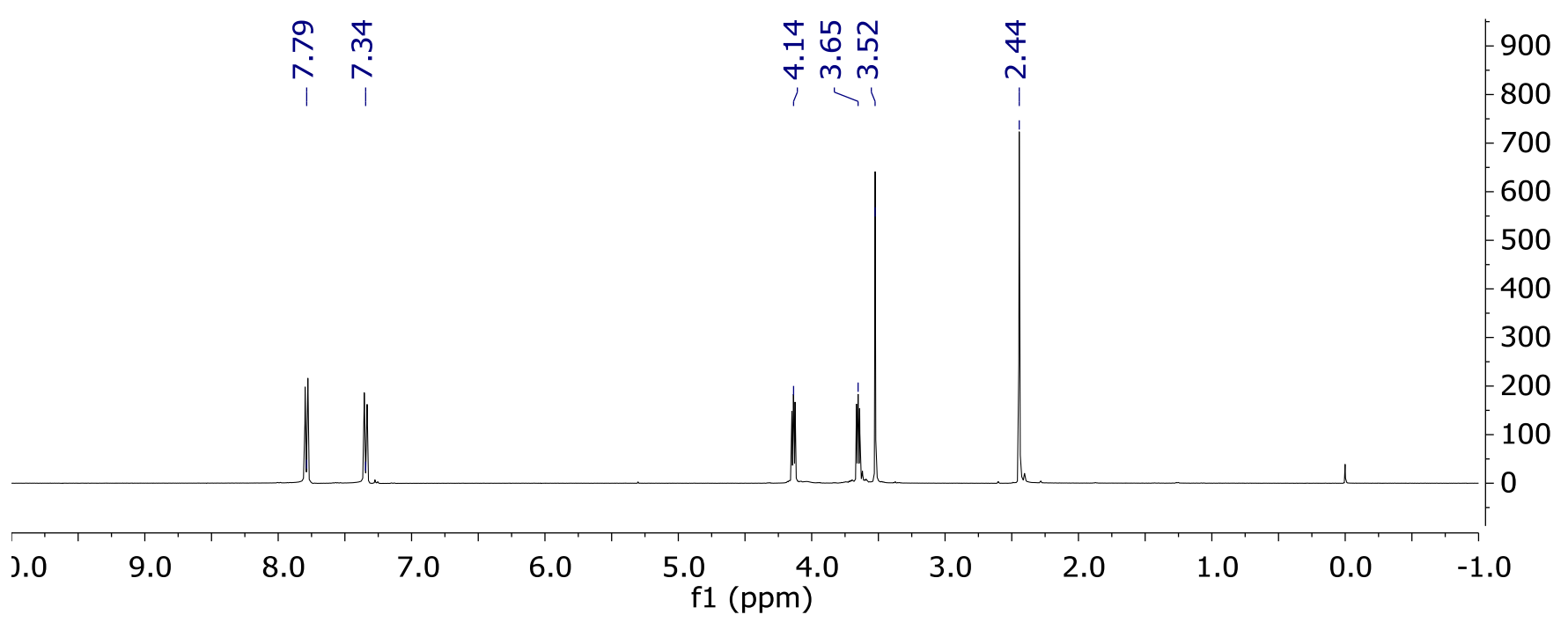

Figure S15. ${ }^{1} \mathrm{H}$ NMR $\left(\mathrm{CDCl}_{3}, 400 \mathrm{MHz}, 298 \mathrm{~K}\right)$ of $\mathbf{S} 1$.

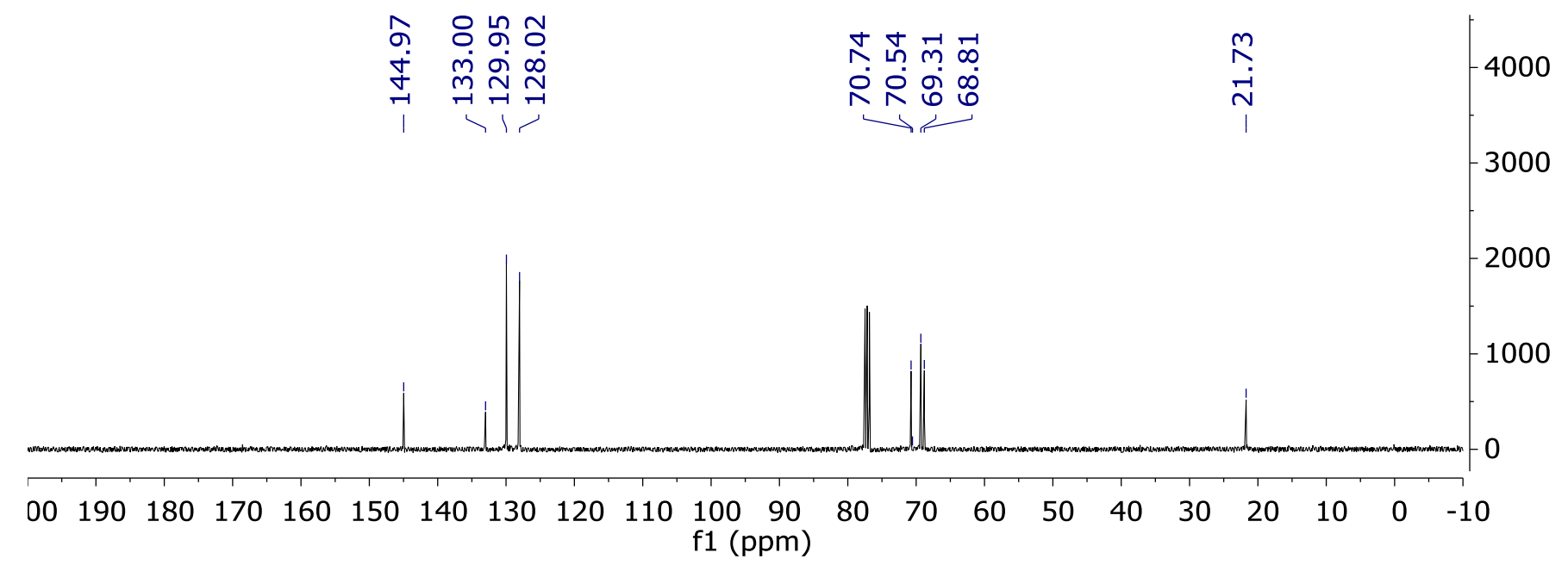

Figure S16. ${ }^{13} \mathrm{C}$ NMR $\left(\mathrm{CDCl}_{3}, 100 \mathrm{MHz}, 298 \mathrm{~K}\right)$ of $\mathbf{S 1}$. 


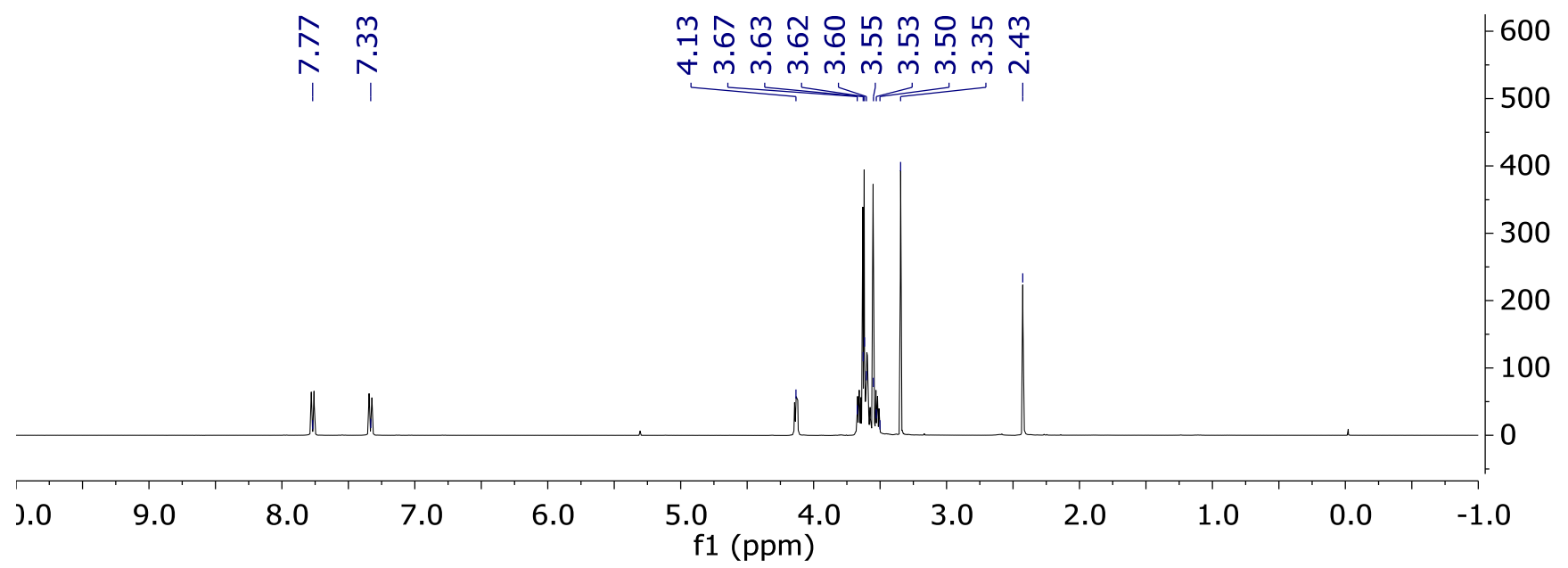

Figure S17. ${ }^{1} \mathrm{H}$ NMR $\left(\mathrm{CDCl}_{3}, 400 \mathrm{MHz}, 298 \mathrm{~K}\right)$ of $\mathbf{S 2}$.

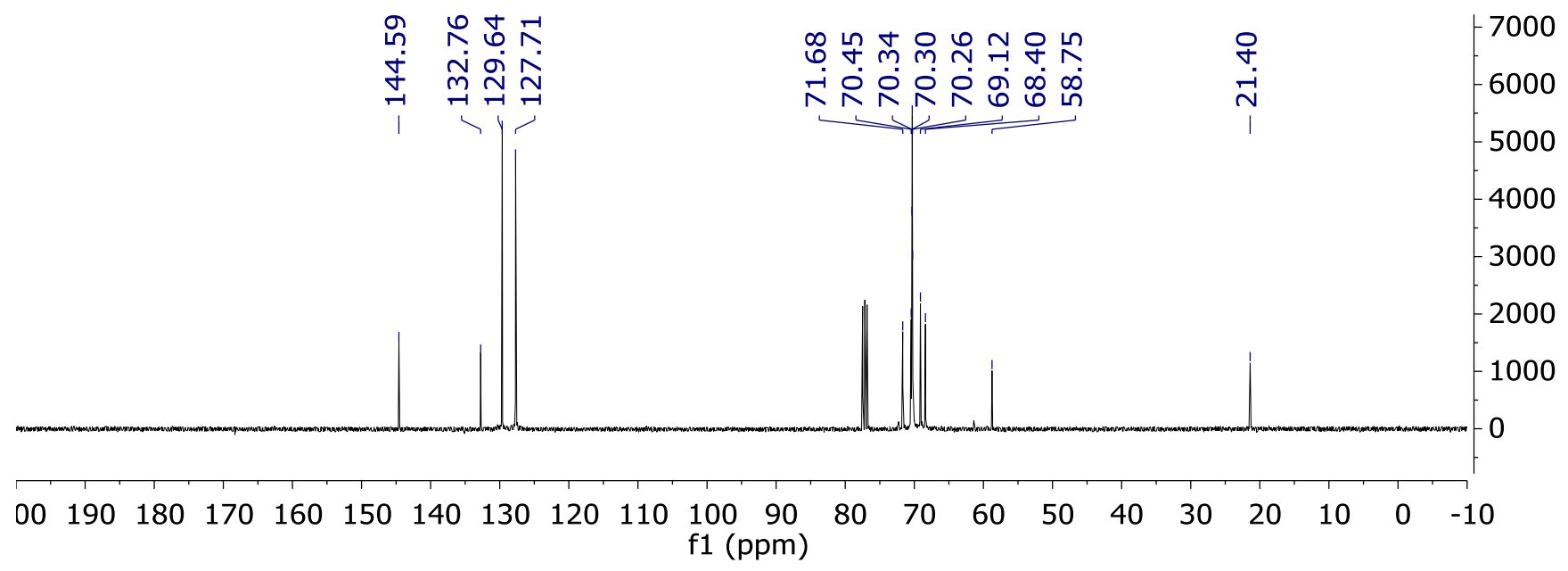

Figure S18. ${ }^{13} \mathrm{C}$ NMR $\left(\mathrm{CDCl}_{3}, 100 \mathrm{MHz}, 298 \mathrm{~K}\right)$ of $\mathbf{S 2}$. 


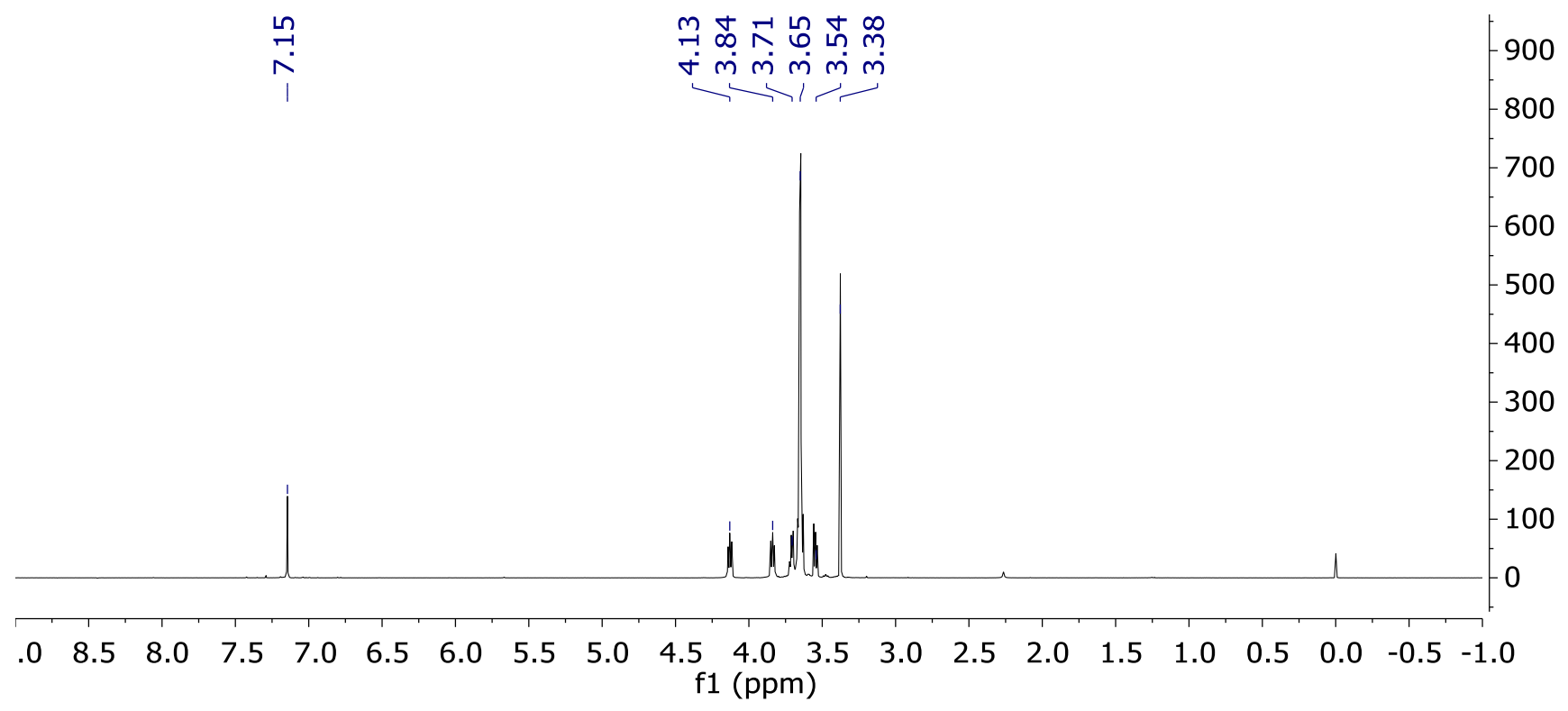

Figure S19. ${ }^{1} \mathrm{H}$ NMR $\left(\mathrm{CDCl}_{3}, 400 \mathrm{MHz}, 298 \mathrm{~K}\right)$ of $\mathbf{S 4}$.

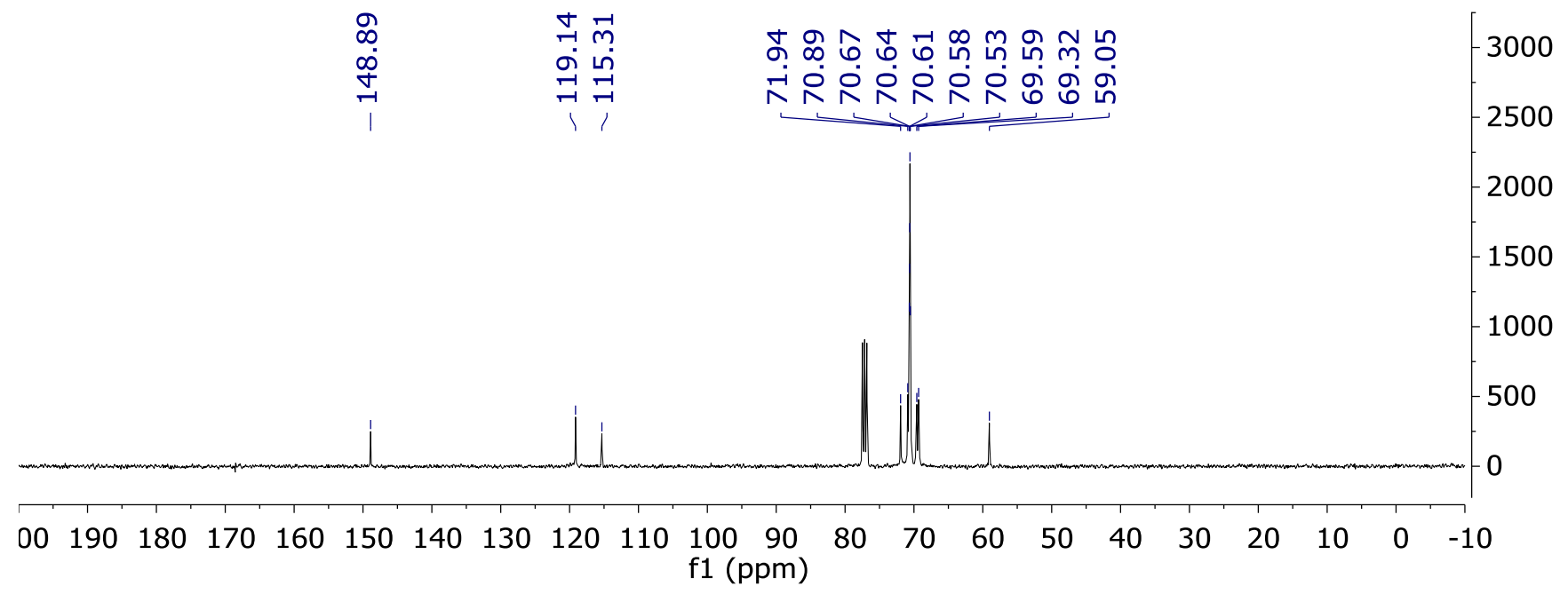

Figure S20. ${ }^{13} \mathrm{C}$ NMR $\left(\mathrm{CDCl}_{3}, 100 \mathrm{MHz}, 298 \mathrm{~K}\right)$ of $\mathbf{S 4}$. 


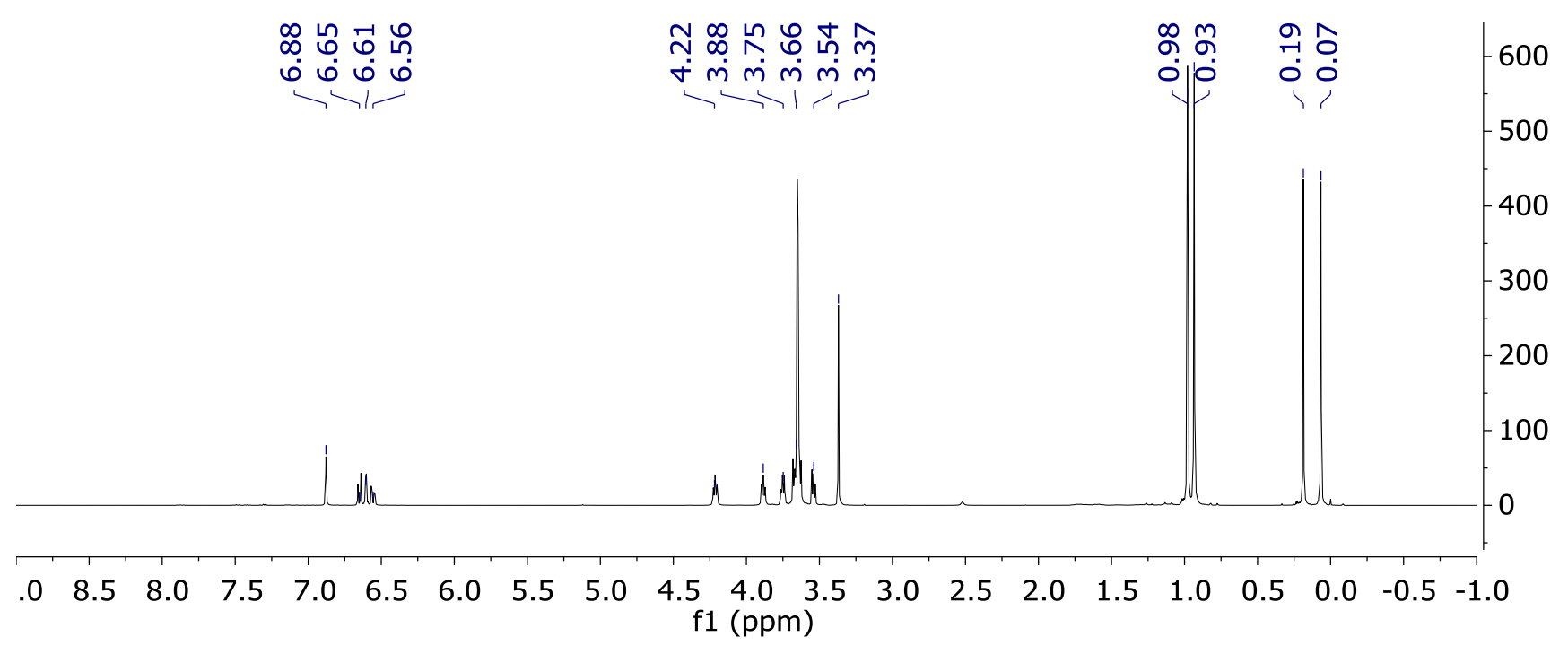

Figure S21. ${ }^{1} \mathrm{H} \mathrm{NMR}\left(\mathrm{CDCl}_{3}, 400 \mathrm{MHz}, 298 \mathrm{~K}\right)$ of $\mathbf{S 6}$.

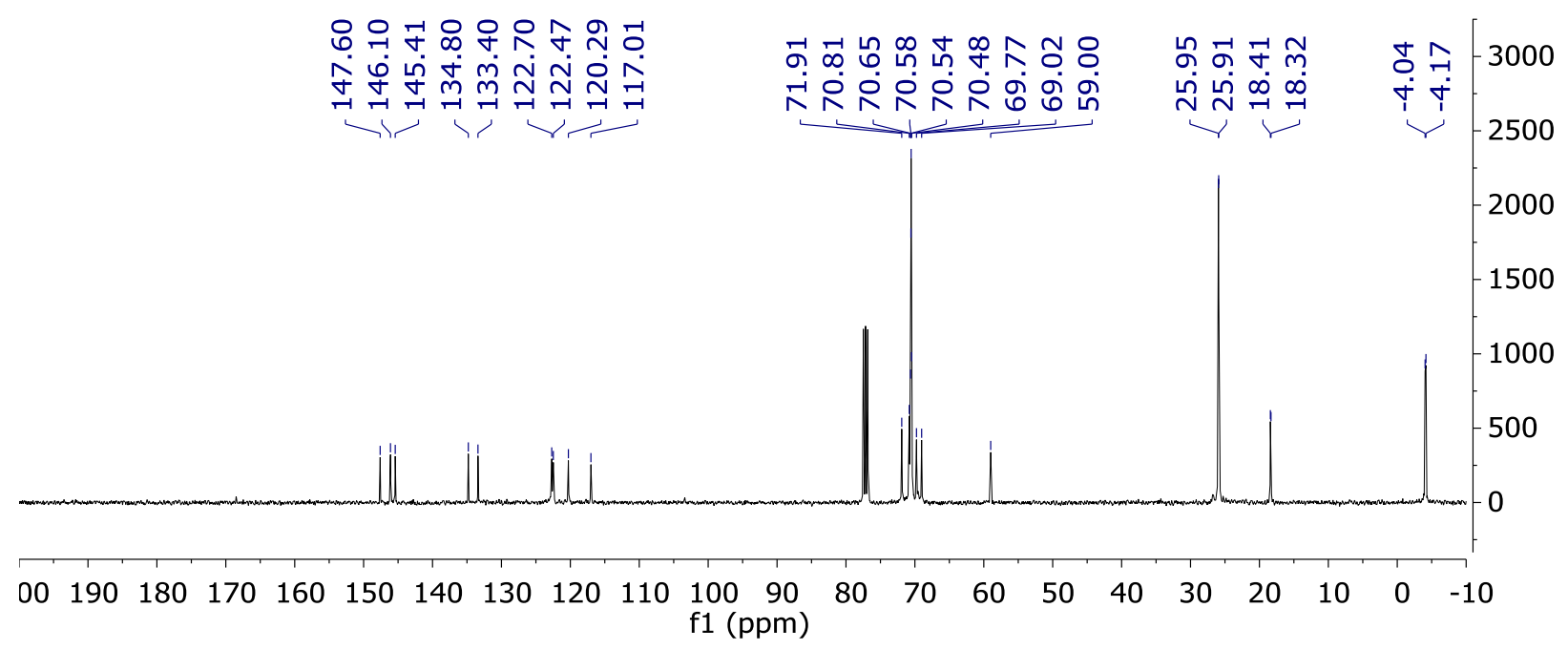

Figure S22. ${ }^{13} \mathrm{C}$ NMR $\left(\mathrm{CDCl}_{3}, 100 \mathrm{MHz}, 298 \mathrm{~K}\right)$ of $\mathbf{S 6}$. 


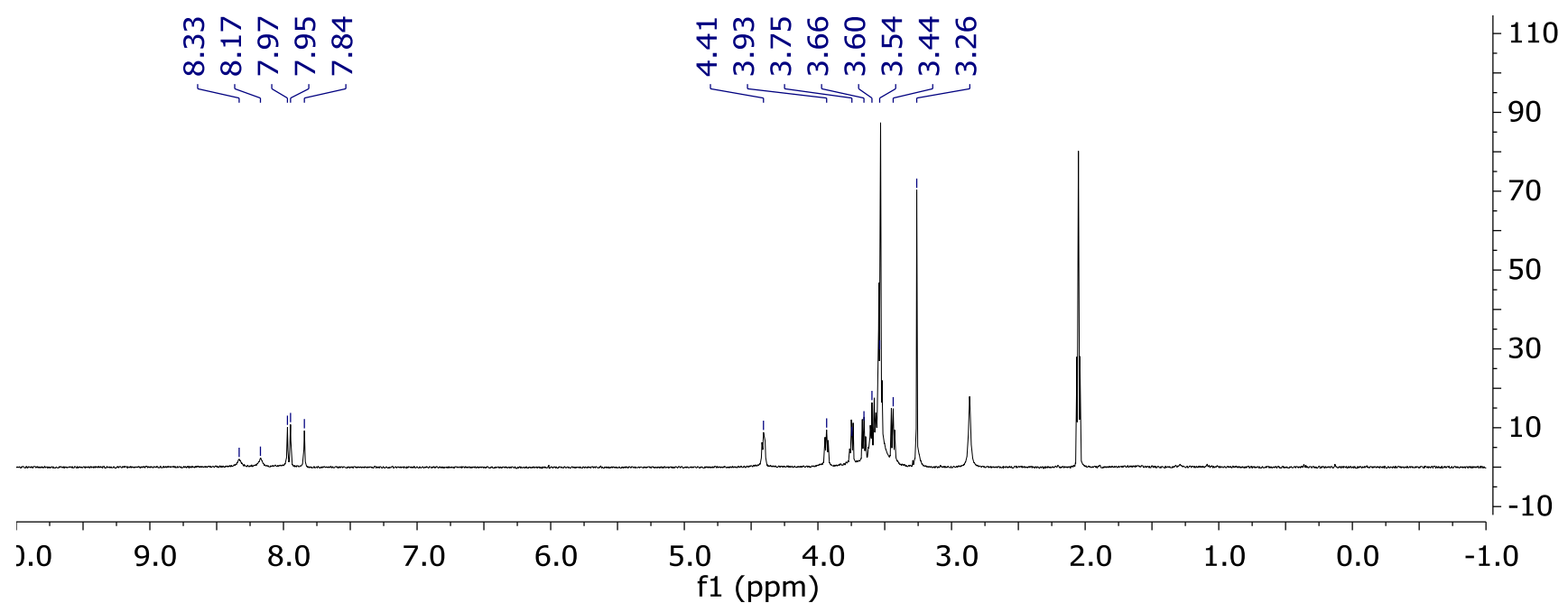

Figure S23. ${ }^{1} \mathrm{H} \mathrm{NMR}\left(\mathrm{CD}_{3} \mathrm{COCD}_{3}, 400 \mathrm{MHz}, 298 \mathrm{~K}\right)$ of $\mathrm{HxgTHTP}$.

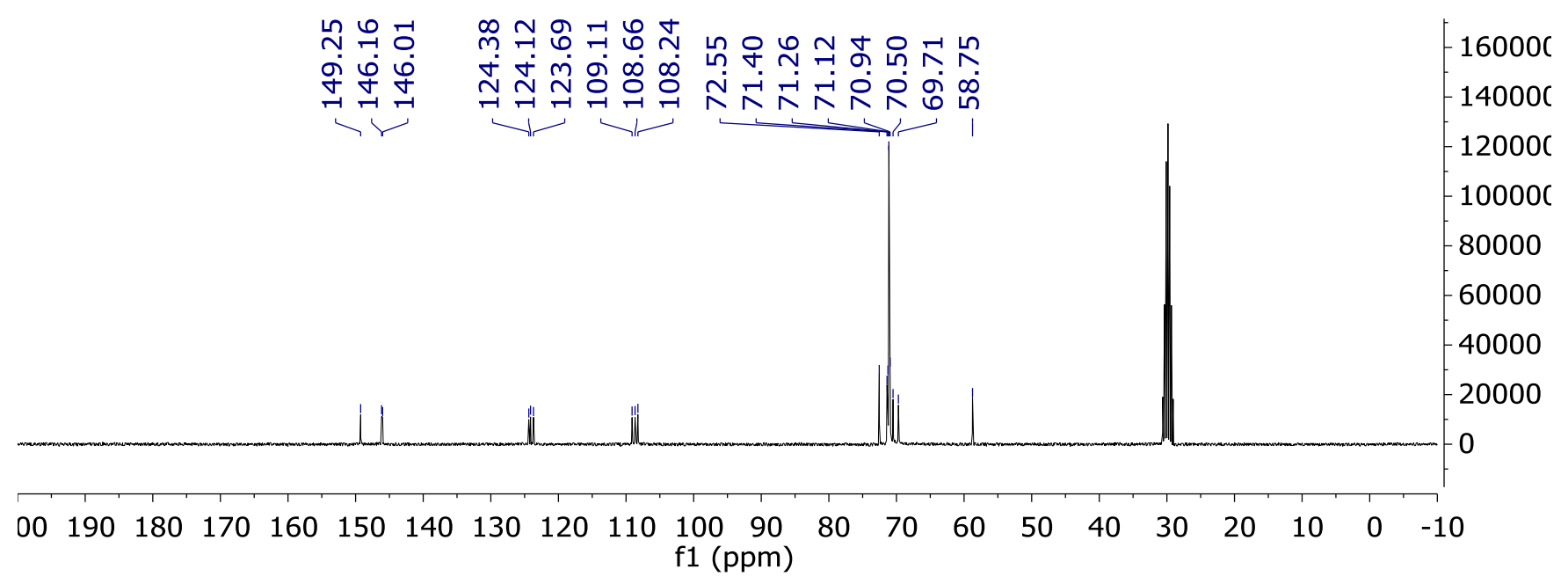

Figure S24. ${ }^{13} \mathrm{C} \mathrm{NMR}\left(\mathrm{CD}_{3} \mathrm{COCD}_{3}, 100 \mathrm{MHz}, 298 \mathrm{~K}\right)$ of $\mathbf{H x g T H T P}$. 


\section{References}

1. Smith, M. K.: Powers-Riggs, N. E.; Northrop, B. H. RSC Adv. 2014, 4, 38281

2. Accelrys, 4.4 ed., Accelrys Software, San Diego, 2008.

3. Metropolis, N.; Rosenbluth, A. W.; Rosenbluth, M. N.; Teller, A. H.; Teller, E. Equation of State Calculations by Fast Computing Machines. J. Chem. Phys., 1953, 21, 1087-1092.

4. J. Ilavsky, Nika - software for 2D data reduction. J. Appl. Cryst. 2012, 45, 324.

5. Smith, B. J.; Dichtel, W. R. J. Am. Chem. Soc. 2014, 136, 8783

6. Friscourt, F.; Fahrni, C. J.; Boons. G.-J. J. Am. Chem. Soc. 2012, 134, 18809-18815

7. Rosso, M.; Nguyen, A. T.; Jong, E. D.; Baggerman, J; Paulusse, J. M. J.; Giesbers, M.; Fokkink, R. G.; Norde, W.; Schroen, K; van Rijn, C. J. M.; Zuilhof, H.; ACS Appl. Mater. Interfaces, 2011, 3, 697-704 